\title{
Playing Doctor: When Crisis Pregnancy Centers and States Blur the Line of Informed Consent
}

\author{
Sasha M. Raab
}

\section{INTRODUCTION}

In 2018, comedian and talk show host John Oliver ran a segment on Last Week Tonight discussing the rise of crisis pregnancy centers (CPCs). ${ }^{1}$ CPCs are nonprofits "posing as pseudo-medical facilities operated by anti-choice activists that aim to coerce women considering abortion into carrying their pregnancies to term."2 On the show, Oliver played a segment of an interview of a rape victim who described in vivid detail the emotional distress she experienced after a CPC staff member provided unsolicited counseling as she walked to the abortion clinic next door. ${ }^{3} \quad$ The segment was an all-too-real depiction of the deceptive practices taking place at these clinics.

The deceptive marketing practices of CPCs lure low-income and marginalized women in the door. ${ }^{4}$ With the marked decrease of abortion clinics in America, women seeking health care have increasingly turned to $\mathrm{CPCs}^{5}$ without realizing the centers' unstated goals. ${ }^{6}$ Oliver pointed

\footnotetext{
* Associate Attorney, Payne \& Jones, Chartered; J.D., 2020, University of Kansas School of Law; B.S., 2015, Park University. I would like to thank the staff and the editorial board of the Kansas Law Review, including Andi Leuszler and Sarah Buchanan, for their time and effort in editing this piece, and especially my good friend Joy Merklen for her rigorous edits and suggestions. I would also like to thank my husband, Edward Raab, who continually supports me in all my endeavors, my daughter, Edith Raab, who inspires me each and every day, and all my other family members and friends for their continued support.

1. Last Week Tonight with John Oliver: Crisis Pregnancy Centers (HBO television broadcast Apr. 8, 2018), https://www.youtube.com/watch?v=4NNpkv3Us1I [https://perma.cc/AVH4-E2LS] [hereinafter Last Week Tonight].

2. NARAL Pro-Choice N.Y. Found., "She SAid ABortion Could Cause Breast CANCER,” A RePORT ON: The Lies, MANipulations, AND PRiVACY VIOlations OF CRisis PREGNANCY CENTERS IN NEW YORK CITY 2 (2010), https://www.nirhealth.org/wp-content/uploads /2015/09/cpcreport2010.pdf [https://perma.cc/QB96-FF5R] [hereinafter NARAL REPORT].

3. Last Week Tonight, supra note 1, at 6:09.

4. See Joanne D. Rosen, The Public Health Risks of Crisis Pregnancy Centers, 44 PERSP. ON SEXUAL \& REPROD. HEALTH 201, 201 (2012).

5. See Ramiro Ferrando, While Abortion Clinics Diminish, Crisis Pregnancy Centers Flourish, MiDWEST CTR. FOR INVESTIGATIVE REPORTING (Feb. 19, 2019), https://investigatemidwest.org /2019/02/19/while-abortion-clinics-diminish-crisis-pregnancy-centers-flourish/ [https://perma.cc
} 
out several deceptive practices, many of which sound research has echoed. The deceptive marketing practices include using language of the reproductive rights movement, referencing "choices," "rights," and "informed decisions" in advertisements, ${ }^{7}$ with targeted Google ads that populate when a person searches "abortion clinic." " Other deceptive tactics include: disguising the anti-abortion viewpoint of the CPC, ${ }^{9}$ refusing to discuss abortion over the phone ${ }^{10}$-requiring women to visit the clinic before discussing abortion-and opening CPCs next to abortion clinics to draw in women seeking abortion services. ${ }^{11}$

Once a woman walks into a CPC, the services it provides only hamper her ability to receive sound medical advice. For example, many CPCs intentionally misread ultrasounds by incorrectly stating the gestational age of the fetus, potentially preventing a woman from seeking an abortion before time runs out in her state. ${ }^{12}$ Others misstate the abortion informed consent laws during counseling, making women believe they have more time to weigh the decision. ${ }^{13}$ Appointments have even been purposely delayed altogether so the fetus is closer to viability before the woman has an ultrasound that accurately states the fetus's gestational age. ${ }^{14}$ This all occurs in a center that has the trappings of a

17676-TXTN] (noting that all but four states have a higher number of CPCs than abortion clinics).

6. See NARAL REPORT, supra note 2, at 9 ("Hiding their anti-abortion agenda and giving the false impression of medical expertise serves the CPCs' dual purpose of confusing, and thereby tricking, women who may be seeking a genuine medical facility, as well as legitimizing the inaccurate information and biased counseling these centers provide.").

7. Id. at 7 ("The Crisis Pregnancy Center of New York website, for example, states, 'You have the legal right to choose the outcome of your pregnancy.", (quoting Options, CRISIS PREGNANCY CTR. OF N.Y., http://www.cpcny.org/options.htm [https://perma.cc/BUF6-JF8E])).

8. NARAL Pro-Choice Am., Crisis Pregnancy Centers LiE: The Insidious ThreAt to REPRODUCTIVE FREEDOM 4 (2015), https://www.prochoiceamerica.org/wp-content/uploads/2017/04 /cpc-report-2015.pdf [https://perma.cc/7JD5-W38U]; see also Last Week Tonight, supra note 1, at $5: 41$.

9. NARAL REPORT, supra note 2, at 8 ("Approximately $75 \%$ of investigated CPCs fail to disclose their anti-choice agenda on their websites, thereby misleading unsuspecting women who may think they are going to visit a clinic that offers medically accurate and unbiased comprehensive reproductive health information and services.").

10. Id. at 7 ("Volunteer investigators reported that, on the phone, the CPCs were welcoming and seemed eager to get the caller to come in for an appointment... . None mentioned abortion unless asked; once asked, most said they did not recommend or refer for abortion.”).

11. Id.

12. Last Week Tonight, supra note 1, at 10:34.

13. See, e.g., NARAL REPORT, supra note 2, at 11 ("[W]hen a volunteer investigator posing as a woman who was 9.3 weeks pregnant asked a counselor at the EMC Pregnancy Center in the Bronx how long she had to make a decision, the counselor told her that 'in this country you can get an abortion up to nine months' and 'you've got time to think about it.' In reality, abortion is prohibited after the point of fetal viability unless a woman's life or health is in danger or if the fetus is not viable.").

14. See S. Malia Richmond-Crum \& Melissa Kleder, NARAL Pro-Choice Md. Fund, 
doctor's office, ${ }^{15}$ where one reasonably expects to be apprised of all the facts in a nonjudgmental manner.

These deceptive practices are reinforced in the rhetoric CPC proponents utilize and the documents staff rely on for counseling to push their hidden anti-abortion agenda. For instance, one proponent, Heartbeat International, provides a handbook for CPCs that contains inaccuracies about the risk of abortion, such as an increased risk of suicide, infertility, and breast cancer. ${ }^{16}$ Abby Johnson, an anti-abortion activist, revealed the deceptive intentions of CPCs when she spoke at the Heartbeat International Annual Conference in 2012: "We want to appear neutral on the outside. The best client you ever get is one that thinks they're walking into an abortion clinic. Okay? Those are the best clients that could ever walk in your door or call your center - the ones that think you provide abortions." 17 These deceptive practices are intentionally employed to reduce the availability of abortion and advance the antiabortion agenda. At the heart of this issue is the disconnect between those who view abortion as morally wrong, ${ }^{18}$ and those who view abortion as a medical procedure, with the expectation that any clinic specializing in pregnancy services should be held to medical standards.

Despite the dangers of these deceptive marketing tactics, few states

Maryland Crisis Pregnancy Center Investigations: The Truth Revealed (2008), https:// maryland.prochoiceamericaaffiliates.org/wp-content/uploads/sites/11/2018/04/crisispregnancycenter report.pdf [https://perma.cc/L9LA-9TSV] ("CPCs purposefully schedule sonogram appointments two-three weeks after the initial appointment to ensure that there will be a heartbeat and that the pregnancy is larger than a grain of rice.").

15. See nat'l abortion Fed'n, Crisis Pregnancy Centers: An Affront to Choice 4 (2006), https://www.prochoice.org/wp-content/uploads/cpc_report.pdf [https://perma.cc/6FCK -XFF8] ("CPCs often design their facilities to look like actual health care facilities with a waiting room, a partitioned check-in desk, and an ultrasound machine."); see also Last Week Tonight, supra note 1, at 9:14 (explaining that CPCs mislead women by branding themselves as healthcare facilities); Vice News, The Fake Abortion Clinics of America: Misconception, YouTuBE (Sept. 17, 2014), https://www.youtube.com/watch? $=$ g-ex4Q-z-is [https://perma.cc/LUC4-85B4] (documenting CPCs mispresenting themselves as healthcare facilities).

16. Last Week Tonight, supra note 1, at 8:15; see also NARAL REPORT, supra note 2, at 9 ("Nearly every CPC investigated provided misleading - or sometimes entirely false-information about abortion, either through websites, written materials, or counseling sessions. They portrayed abortion as a painful, dangerous procedure that leads to a range of physical and emotional damage: future infertility, higher risk of breast cancer, 'post-abortion syndrome,' and other health complications, including sexual dysfunction, infection, cervical scarring, and death.").

17. Last Week Tonight, supra note 1, at 3:18.

18. See, e.g., Timothy Brahm, John Oliver's Lies About Abby Johnson and Crisis Pregnancy Centers, EQUAL RighTS InST. BLOG (Apr. 18, 2018), https://blog.equalrightsinstitute.com/john -olivers-lies-about-abby-johnson-and-crisis-pregnancy-centers/ [https://perma.cc/7BYE-TPA2] (last visited Mar. 31, 2020) (criticizing Oliver's view of CPCs and defending the centers' tactics). Abby Johnson does not view these tactics as deceptive. Id. Anti-abortion activists allege that they view these tactics as efforts to "do everything we can while remaining moral to try to get abortion-minded women into the center." Id. 
regulate or have attempted to regulate $\mathrm{CPCs}^{19}$ and some states, including Kansas, endorse CPCs. ${ }^{20}$ California was one of the states that attempted to regulate CPCs. In 2015, California passed the Reproductive Freedom Accountability, Comprehensive Care, and Transparency Act ${ }^{21}$ (FACT Act) to inform low-income women who enter CPCs of their options. ${ }^{22}$ The National Institute of Family and Life Advocates - an organization that operates over 1,400 CPCs - and two California CPCs challenged the FACT Act on First Amendment grounds in National Institute of Family and Life Advocates v. Becerra (NIFLA). ${ }^{23}$ The NIFLA Court held that strict scrutiny presumptively applies to content-based laws that regulate speech, with only two narrow exceptions. The Court found that the petitioners were likely to succeed on the merits, signaling the lower court to issue a preliminary injunction to enjoin the FACT Act. ${ }^{24}$ NIFLA may have far-reaching implications for not only disclosure requirements in the abortion context but also disclosure requirements writ large. ${ }^{25}$ The logic behind NIFLA perpetuates a paternalistic ideology aiming to dissuade women from seeking abortion services, ${ }^{26}$ and adopts a standard that is not evenhandedly applied to abortion providers' First Amendment

19. Are We a Medical Clinic?, HeARTBEAT INT'L, https://www.heartbeatinternational.org/are -we-a-medical-clinic [https://perma.cc/Y7TW-TZPJ] (last visited Apr. 13, 2020) (listing California, New York, Massachusetts, and New Jersey as the only four states that regulate, or have attempted to regulate, CPCs); see also Crisis Pregnancy Centers, REWIRE.NEws, https://rewire.news/legislative -tracker/law-topic/crisis-pregnancy-centers/ [https://perma.cc/J24G-7TTK] (last updated Sept. 12, 2018) ("In 2009, Baltimore became the first city to enact an ordinance requiring limited-service pregnancy centers to post signs in their waiting rooms indicating that such centers do not provide or make referrals for abortion or birth-control services. A similar ordinance was passed in Montgomery County, Maryland, requiring centers to post signs indicating the lack of licensed medical providers on staff. Both ordinances were later blocked by federal courts. Similar local ordinances in Texas and New York have also been blocked and/or revised in court.").

20. See S. Con. Res. 1606, 2013 Leg., Reg. Sess. (Kan. 2013) (enacted).

21. Cal. Health \& SAFETy Code $\S \S 123470-123473$ (West Supp. 2018).

22. See A.B. 775, 2015-2016 Leg., Reg. Sess., §1(a) (Cal. 2015) (“All California women, regardless of income, should have access to reproductive health services. The state provides insurance coverage of reproductive health care and counseling to eligible, low-income women.... Because pregnancy decisions are time sensitive, and care early in pregnancy is important, California must supplement its own efforts to advise women of its reproductive health programs.").

23. 138 S. Ct. 2361, 2370 (2018).

24. Id. at 2378 .

25. See id. at 2380 (Breyer, J., dissenting) (arguing that the majority's approach "threatens considerable litigation over the constitutional validity of much, perhaps most, government regulation").

26. See Ian Vandewalker, Abortion and Informed Consent: How Biased Counseling Laws Mandate Violations of Medical Ethics, 19 MiCH. J. GENDER \& L. 1, 8 (2012) ("The Supreme Court's abortion jurisprudence in Casey and since touches on informed consent principles and women's autonomy. Apparent in these decisions is a troubling strain of paternalism and distrust of women's decision-making ability."). 
rights. $^{27}$

This Comment analyzes First Amendment principles that apply to compelled physician speech and argues that NIFLA must apply evenly to all state-mandated disclosures and uphold only regulations based in fact that are sufficiently tied to medical treatment and that a patient would want to know before making a medical decision. Adding the element of what a reasonable patient would want to know-an informed consent requirement - to the NIFLA standard would require state-mandated disclosure laws to apply with equal force to the medical providers who offer abortions and those who do not, resolving the inequity NIFLA implies. This Comment further argues that, while strict scrutiny is not necessarily fatal in fact, the FACT Act does not survive strict scrutiny. This result, while seemingly unfavorable, offers a path for successfully challenging abortion informed consent laws as unconstitutional compelled speech requiring physicians to espouse the controversial and ideological views of the state.

Part II traces the legal context, history, and current status of the informed consent doctrine. It then puts the informed consent doctrine into perspective and discusses the Court's abortion jurisprudence. Next, it summarizes informed consent in the context of a medical provider's First Amendment free speech concerns. Finally, Part II discusses NIFLA and the inequities it creates.

Section III.A argues that states may pass protective measures to safeguard patients who may otherwise be uninformed or disadvantaged. It begins by unwrapping the rule set forth in NIFLA and argues that the Supreme Court overlooked precedent and adopted a rule that obscures precedent. Section III.B then explains that, despite NIFLA's recognition of only two narrow exceptions to the general rule that strict scrutiny applies to content-based regulations, strict scrutiny is not necessarily fatal. $^{28}$ The FACT Act, however, is not narrowly tailored to achieve California's compelling interest in protecting pregnant people because it is too broad.

Section III.C applies the NIFLA standard to informed consent

27. NIFLA, 138 S. Ct. at 2385 (Breyer, J., dissenting) ("If a State can lawfully require a doctor to tell a woman seeking an abortion about adoption services," as in Planned Parenthood of Southeastern Pennsylvania v. Casey, "why should it not be able, as here, to require a medical counselor to tell a woman seeking prenatal care or other reproductive healthcare about childbirth and abortion services?").

28. See Burson v. Freeman, 504 U.S. 191, 211 (1992) (finding a content-based regulation of speech passed a strict scrutiny standard of review); see also Holder v. Humanitarian Law Project, 561 U.S. 1, 40 (2010) (finding a content-based regulation of speech that limited "forms of support ... to terrorist organizations" passed strict scrutiny). 
statutes in effect in Kansas, South Dakota, and Indiana. ${ }^{29}$ These informed consent laws are good examples of the controversial disclosure requirements states impose on abortion providers. This Section argues that these informed consent laws are state ideological speech masquerading as medically necessary information and if challenged, strict scrutiny would apply and the statutes would fail. Next, it argues that NIFLA gives physicians a leg to stand on to invalidate ideological abortion informed consent laws. Lastly, Section III.D proposes a redraft of the relevant section of the Reproductive FACT Act to comply with NIFLA.

\section{BACKGROUND}

A society concerned with the politics of reproductive rights rather than medical ethics has fostered the emergence of CPCs and increased legislative abortion restrictions. ${ }^{30}$ Many states have enacted burdensome and medically unnecessary regulations on abortion providersregulations not imposed on other medical professionals. ${ }^{31}$ Commonly referred to as TRAP (Targeted Regulation of Abortion Providers) laws, these regulations are designed to shut down abortion clinics and impede access to abortion. ${ }^{32} \mathrm{CPCs}$, on the other hand, are vastly underregulated. $^{33}$ This Part discusses the history of informed consent laws and the tactics CPCs use to disguise their anti-abortion stance under

29. Dennis Carter, Kansas Republicans Scramble to Override 'Fundamental' Right to Abortion: Spotlight on the States (Updated), REWIRE.NEWS (Feb. 7, 2020, 5:34 PM), https://rewire.news /article/2020/02/03/kansas-republicans-fundamental-right-abortion-spotlight-on-the-states/ [https:// perma.cc/KCJ4-5Q3W].

30. See Rosen, supra note 4, at 201-03 (explaining that CPCs often misinform low-income women about contraception and abortion, and noting that to combat the negative effects of this information, states could enforce "state consumer protections laws that prohibit false advertising or deceptive practices by service providers" and "[h]ealth departments could disseminate clear and detailed information about the contraceptive, abortion, pregnancy, and STD services available at the centers, as well as the actual risks related to abortion and the likelihood of those risks").

31. TRAP Laws, NARAL PRO-CHOICE AM., https://www.prochoiceamerica.org/issue/trap-laws/ [https://perma.cc/2Q54-UZUT] (last visited Apr. 13, 2020) (listing states that subject abortion providers to restrictions not imposed on other medical professionals).

32. Id.; see Whole Woman's Health v. Hellerstedt, 136 S. Ct. 2292, 2301 (2016) (noting that Texas regulations of abortion clinics requiring admitting privileges and ambulatory surgical centers standards caused almost half of the state's abortion centers to close).

33. CPCs are only subject to certain applicable regulations, such as HIPAA, if the center is a licensed medical provider. Amy G. Bryant \& Jonas J. Swartz, Why Crisis Pregnancy Centers Are Legal but Unethical, 20 AMA J. ETHICS 269, 271 (2018). Most CPCs, however, are not licensed medical providers. Id. Further, CPC speech has proven difficult to regulate because laws imposing disclosure requirements on CPCs must comply with the First Amendment. Id.; see also Rosen, supra note 4, at 203 (finding that the majority of state legislation seeking to regulate deceptive practices of CPCs have been the subject of litigation and invalidated on First Amendment grounds). 
the guise of informed consent. Then, this Part examines the Supreme Court's abortion and free speech jurisprudence, setting the stage for NIFLA. Lastly, it summarizes NIFLA and highlights the inequities in the holding.

\section{A. Informed Consent}

Today, CPCs far outnumber abortion clinics. ${ }^{34}$ This would not necessarily be a problem if CPCs offered factual and comprehensive advice about abortion. While CPCs claim to provide the marginalized women who seek their services with accurate information about their healthcare options, ${ }^{35}$ however, these centers frequently "provide inaccurate information that may delay or interfere with women's access to abortion and contraceptive services, improperly influence women's reproductive health decisions and potentially increase the number of unintended births." 36 These deceptive practices violate the ethical standard of informed consent.

\section{History and Current Definition}

The informed consent doctrine has its origins in medical ethics and common law torts. ${ }^{37}$ The concept of informed consent first arose in the context of battery cases. ${ }^{38}$ Early cases recognized a person's right to have "complete immunity of [their] person from medical interference of others." 39 As Justice Cardozo announced in the landmark decision of Schloendorff v. Society of New York Hospital, "[e]very human being of adult years and sound mind has a right to determine what shall be done with his own body; and a surgeon who performs an operation without his patient's consent commits an assault, for which he is liable in damages." 40 The right, however, was solely a right of refusal - the early

34. See Brittany A. Campbell, Note, The Crisis Inside Crisis Pregnancy Centers: How to Stop These Facilities from Depriving Women of Their Reproductive Freedom, 37 B.C. J.L. \& Soc. JusT. 73, 79 (2017) ("Nationwide, CPCs outnumber legitimate abortion clinics three-to-one . . ..”).

35. NAT'L ABORTION FED'N, supra note 15, at 8 .

36. Rosen, supra note 4, at 201.

37. Margaret E. Swain, The Essentials of Informed Consent: What ART Clients Don't Know Can Hurt Them!, 34 FAM. ADVOC. 18, 19 (2011).

38. Id.

39. Mohr v. Williams, 104 N.W. 12, 16 (Minn. 1905) (battery claim against a physician for operating on the wrong ear without the patient's consent); see also Pratt v. Davis, 118 Ill. App. 161, 166 (1905) (“[T]he free citizen's first and greatest right, which underlies all others- the right to the inviolability of [their] person ...."), aff'd, 79 N.E. 562 (1906).

40. 105 N.E. 92,93 (N.Y. 1914). 
cases did not recognize the right to disclosure of additional information. ${ }^{41}$ Over time, courts began to apply negligence concepts, rather than intentional tort concepts, viewing the failure to provide informed consent as a breach of the physician's duty to their patient, rather than a claim rooted in battery, and a duty to inform the patient of the risks and benefits emerged as a requirement. ${ }^{42}$

Black's Law Dictionary defines informed consent as "[a] patient's knowing choice about a medical treatment or procedure, made after a physician or other healthcare provider discloses whatever information a reasonably prudent provider in the medical community would give to a patient regarding the risks involved in the proposed treatment or procedure." ${ }^{43}$ The informed consent doctrine places responsibility on the medical provider to rise to the standard of a reasonable and prudent professional. ${ }^{44}$ The corollary in the medical community is substantively the same. ${ }^{45}$

The informed consent process consists of three elements: (1) communication of sufficient information regarding the risks, benefits, and alternatives, ${ }^{46}(2)$ comprehension of the conveyed information, ${ }^{47}$ and

41. Swain, supra note 37, at 19-20.

42. Id; see also Robert Gatter, Informed Consent Law and the Forgotten Duty of Physician Inquiry, 31 LOY. U. CHI. L.J. 557, 561-62 (2000) ("The doctrine of informed consent provides patients with two causes of action against a treating physician: one for providing treatment without any consent, and another for failing to sufficiently disclose treatment information to allow for truly informed consent. . . To plead a claim for failure to disclose treatment information, a patient must allege that: (1) the physician had a duty to disclose the particular information; (2) the physician breached this duty; and (3) the physician's breach caused an injury to the patient.").

43. Informed Consent, BLACK's LAW DiCTIONARY (11th ed. 2019).

44. See Gatter, supra note 42 , at 566 ("The prudent physician standard requires physicians to disclose information that a reasonably prudent physician in the same or similar circumstances would disclose.").

45. See Informed Consent, AM. MED. Ass'N, https://www.ama-assn.org/delivering-care/ethics /informed-consent [https://perma.cc/B8RZ-PEVL] (last visited Apr. 5, 2020) [hereinafter Informed Consent, AM. MED. ASS'N] ("The process of informed consent occurs when communication between a patient and physician results in the patient's authorization or agreement to undergo a specific medical intervention. In seeking a patient's informed consent . . physicians should: (a) Assess the patient's ability to understand relevant medical information and the implications of treatment alternatives and to make an independent, voluntary decision[;] (b) Present relevant information accurately and sensitively, in keeping with the patient's preferences for receiving medical information.").

46. NAT'L COMM'N FOR the Prot. OF HuMAN SUBJECTS OF BIOMEDiCAL \& BeHAVIORAL RESEARCH, THE BELMONT REPORT: ETHICAL PRINCIPLES AND GUIDELINES FOR THE PROTECTION OF HUMAN SUBJECTS OF RESEARCH (1979), https://www.hhs.gov/ohrp/sites/default/files/the-belmont -report-508c_FINAL.pdf [https://perma.cc/6556-9BK2] ("Relevant risks and benefits must be thoroughly arrayed in documents and procedures used in the informed consent process.").

47. Id. ("Even when some direct benefit to them is anticipated, the subjects should understand clearly the range of risk and the voluntary nature of participation."). 
(3) subsequent voluntary consent to treatment. ${ }^{48}$ Critically, in communicating such information, a physician may not withhold material facts or de-emphasize the known risks of a procedure to induce consent. $^{49}$ In practice, informed consent takes place during a conversation between a medical provider and a patient, which can be reinforced with a document. ${ }^{50}$ The medical provider may then record the date informed consent took place and to follow internal protocols. ${ }^{51}$

Informed consent principles, long recognized at common law, ${ }^{52}$ have also been adopted in state statutes, ${ }^{53}$ which occasionally even make the failure to obtain informed consent before an abortion a crime. ${ }^{54}$ While informed consent is a requirement for all medical treatment, most state informed consent statutes regulate abortion and provide stricter requirements for abortions than any other medical procedure. ${ }^{55}$

\section{State Informed Consent Laws}

States uniformly recognize a need for medical providers to obtain informed consent from patients before any medical intervention. ${ }^{56}$ Statutory requirements for informed consent in the abortion context vary from state to state. ${ }^{57}$ Some statutes require disclosure of medically

48. Id. ("This element of informed consent requires conditions free of coercion and undue influence.").

49. Salgo v. Leland Stanford Jr. Univ. Bd. of Trs., 317 P.2d 170, 181 (Cal. Dist. Ct. App. 1957).

50. Dan J. Tennenhouse, 1 AtTorneys Medical Deskbook § 10:70 (4th ed. 2008 \& 2019 Supp.).

51. Id.

52. Reprod. Health Servs. of Planned Parenthood of St. Louis Region, Inc. v. Nixon, 185 S.W.3d 685, 690 (Mo. 2006).

53. See, e.g., GA. CODE ANN. § 31-9-6.1 (West, Westlaw through Laws 2020, Act 322) (requiring informed consent in surgical procedures that involve "general anesthesia, spinal anesthesia, or major regional anesthesia or any person who undergoes an amniocentesis diagnostic procedure or a diagnostic procedure which involves the intravenous or intraductal injection of a contrast material"); 40 PA. STAT. AND CONS. STAT. ANN. $\$ 1303.504$ (West, Westlaw through 2020 Reg. Sess.) (“[A] physician owes a duty to a patient to obtain ... informed consent.").

54. S.D. CODIFIED LAws § 34-23A-10.2 (Westlaw through 2020 Reg. Sess.) ("A physician who, knowingly or in reckless disregard, violates $\S 34-23 \mathrm{~A}-2.1,34-23 \mathrm{~A}-7$, or $34-23 \mathrm{~A}-10.1$ is guilty of a Class 2 misdemeanor.").

55. Kali Ann Trahanas, Comment, How the Undue Burden Standard Is Eroding Informed Consent, 10 Seton Hall CiR. Rev. 231, 239 (2013).

56. For a survey of informed consent cases across the country, see Laurent B. Frantz, Annotation, Modern Status of Views as to General Measure of Physician's Duty to Inform Patient of Risks of Proposed Treatment, 88 A.L.R.3d 1008 (1978 \& Supp. 2020).

57. See Harper Jean Tobin, Confronting Misinformation on Abortion: Informed Consent, Deference, and Fetal Pain Laws, 17 COLUM. J. GENDER \& L. 111, 111-14 (2008) (discussing the various state requirements for physicians obtaining informed consent). 
inaccurate information ${ }^{58}$ and information entirely unrelated to the abortion procedure. These requirements seek to add weight to a woman's decision to terminate her pregnancy, such as making the fetal heartbeat audible, ${ }^{59}$ mandatory waiting periods, ${ }^{60}$ and ultrasounds. ${ }^{61}$ States requiring abortion providers to first conduct an ultrasound do not expressly require the use of a transvaginal ultrasound, but many require that the ultrasound image contain a level of detail that only a transvaginal ultrasound can achieve at early gestational stages. ${ }^{62}$ In practice, these ultrasound requirements thus frequently subject women unnecessarily to invasive transvaginal ultrasounds. ${ }^{63}$

Some states, such as Kansas, push the definition of informed consent even further to require that abortion providers provide information on the gestational age of the fetus, fetal development throughout pregnancy, and fetal pain. ${ }^{64}$ Some statutes that require the provider to display and describe the ultrasound image regardless of the patient's wishes, often termed "speech and display" laws, have been enjoined on free speech grounds. ${ }^{65}$ The current informed consent landscape has been irrefutably shaped by anti-abortion activists who do not intend to make a woman more informed in her medical decision. Rather, the intention is to inform

58. See Counseling and Waiting Periods for Abortion, GUTTMACHER INST., https://www.guttmacher.org/state-policy/explore/counseling-and-waiting-periods-abortion [https:// perma.cc/8AM6-KA6K] (last updated Apr. 1, 2020). See, e.g., KAn. StAT. AnN. § 656709(a)(1)(3), (b)(5) (West 2018) (requiring physicians to disclose, among other risks, the risk to breast cancer and future infertility and to disclose that the "abortion will terminate the life of a whole, separate, unique, living human being”); MISS. CODE. ANN. § 41-41-33(1)(a)(ii) (West, Westlaw through 2020 Reg. Sess.) (requiring patients to be informed of "[t]he particular medical risks associated with the particular abortion procedure ... including, when medically accurate, the risks of infection, hemorrhage and breast cancer, and the danger to subsequent pregnancies and infertility").

59. See, e.g., Tex. Health \& SAFety Code AnN. § 171.012(a)(5) (West, Westlaw through 2019 Reg. Sess.); OKLA. STAT. ANN. tit. 63, § 1-745.14 (West, Westlaw through 57th 2d Reg. Sess.).

60. See Counseling and Waiting Periods for Abortion, supra note 58.

61. See Requirements for Ultrasound, GUTTMACHER INST., https://www.guttmacher.org/state -policy/explore/requirements-ultrasound [https://perma.cc/GF8P-YUQ2] (last updated Apr. 1, 2020).

62. Forced Ultrasound, REWIRE.NEWS, https://rewire.news/legislative-tracker/law-topic/forced -ultrasound/ [https://perma.cc/A8JR-GMTV] (last updated Sept. 12, 2018).

63. Id.

64. Counseling and Waiting Periods for Abortion, supra note 58; see also infra Section III.C.1.

65. See, e.g., Stuart v. Huff, 834 F. Supp. $2 d 428$ (M.D.N.C. 2011) (granting preliminary injunction on the grounds that the speech-and-display requirements of North Carolina's Right to Know Act "violate[d] the First Amendment by compelling unwilling speakers to deliver the state's message discouraging abortion" and the state failed to show these requirements furthered a compelling state interest). The Oklahoma Supreme Court also struck Oklahoma's speech-anddisplay law, but on alternate grounds. See Nova Health Sys. v. Pruitt, 292 P.3d 28 (Okla. 2012). 
women on subjective religious choices ${ }^{66}$ and to "put a face on that baby [that] humanizes this process and really allows the mother to connect" 67 in order to discourage her from choosing abortion. ${ }^{68}$

\section{Crisis Pregnancy Centers and Informed Consent}

CPCs envision "an abortion-free America." 69 To accomplish this tall task, large Christian nonprofits support CPCs by providing legal resources and protection. ${ }^{70}$ Some CPCs provide several services for free. ${ }^{71}$ Those services often come at a high cost to marginalized women because CPCs intentionally mislead pregnant women with inaccurate information that may delay them from receiving unbiased obstetrical care, access to abortion and contraception, or information about federal and state benefit programs. ${ }^{72} \mathrm{CPCs}$, which do everything in their power to dissuade patients from obtaining an abortion, have been the subject of

66. See, e.g., Our Commitment, HeARTBEat InT'L, https://www.heartbeatinternational.org /about/our-commitment [https://perma.cc/ZQ4E-F2BL] (last visited Apr. 2, 2020) ("All Heartbeat International policies and materials are consistent with Biblical principles and with orthodox Christian . . . ethical principles and teaching on the dignity of the human person and sanctity of human life."); About NIFLA, NAT'L INST. OF FAMILY \& LIFE ADVOCATES, https://nifla.org/about -nifla/ [https://perma.cc/Z2XM-7XD6] (last visited Apr. 2, 2020) (describing itself as a "faith-based nonprofit ... seek[ing] to advance the cause and culture of life in America").

67. Kevin Sack, In Ultrasound, Abortion Fight Has New Front, N.Y. TiMES (May 27, 2010), https://www.nytimes.com/2010/05/28/health/policy/28ultrasound.html [https://perma.cc/6ZT9 -TWC7] (quoting Carrie Gordon Earll, a spokesperson for Focus on the Family).

68. See, e.g., Stuart v. Loomis, 992 F. Supp. 2d 585, 588 (M.D.N.C. 2014) (describing North Carolina's Woman's Right to Know Act as "an effort by the state to require health care providers to deliver information in support of the state's philosophic and social position discouraging abortion and encouraging childbirth"), aff'd sub nom. Stuart v. Camnitz, 774 F.3d 238 (4th Cir. 2014).

69. About NIFLA, supra note 66.

70. $I d$.

71. See, e.g., INSIGHT WOMEN's CTR., http://insightlawrence.org [https://perma.cc/8N4L -H8KM] (last visited Apr. 2, 2020); see also About Advice \& Aid Pregnancy Centers: Your Pregnancy Center... Your Friend, ADVICE \& AID, https://adviceandaid.com/advice-aid/ [https://perma.cc/ED4U-EWDX] (last visited Apr. 2, 2020).

72. See Last Week Tonight, supra note 1, at 8:13 (discussing the misleading information and delay tactics CPCs use to dissuade women from choosing abortion); Campbell, supra note 34, at 7778 (stating that CPCs target "vulnerable pregnant women" to lure them into their facilities where they then "intentionally disseminate misleading and often false information"). While the Hyde Amendment to the Medicaid Act limits the use of Medicaid funding for abortions, the current version of the amendment allocates funding for abortions when "the pregnancy is the result of an act of rape or incest" or when the pregnancy "place[s] the woman in danger of death unless an abortion is performed," Consolidated Appropriations Act, 2010, Pub. L. No. 111-117, § 508, 123 Stat. 3034, 3280 (2009). For an overview of the Hyde Amendment and its impact on women, see Maggie Astor, What Is the Hyde Amendment? A Look at Its Impact as Biden Reverses His Stance, N.Y. TIMES (June 7, 2019), https://www.nytimes.com/2019/06/07/us/politics/what-is-the-hyde-amendment.html [https://perma.cc/SHC2-HXBH]. 
extensive litigation for deceptive trade practices, $^{73}$ civil rights violations ${ }^{74}$ and intentional infliction of emotional distress. ${ }^{75}$

\section{B. The Supreme Court's Abortion Jurisprudence}

The Supreme Court's abortion jurisprudence demonstrates the standard of review has evolved from a strict scrutiny standard to the undue burden test, which minimized the right to abortion to a type of intermediate standard subject to state regulation. The Court in NIFLA continued to minimize abortions rights via the First Amendment. In Roe v. Wade ${ }^{76}$ the Supreme Court recognized that the fundamental right to privacy protected by the Fourteenth Amendment's Due Process Clause encompasses the right to terminate a pregnancy. ${ }^{77}$ The Court held that the Constitution protects the right to terminate a pregnancy before viability. ${ }^{78}$ Because the Court declared that abortion is a fundamental right, it determined that regulations limiting the right to abortion are subject to strict scrutiny. ${ }^{79}$ To pass strict scrutiny, regulations limiting abortion needed to be narrowly tailored to achieve a compelling state interest. ${ }^{80}$ Roe found that the state has an interest in protecting maternal health and in protecting potential life-interests that become "compelling" as a pregnancy progresses. ${ }^{81}$ To balance the state's interests against the woman's fundamental right, Roe established a trimester framework to assess regulations limiting abortion. ${ }^{82}$ During the first trimester, the state could not regulate abortions. ${ }^{83}$ After the first

73. See, e.g., Mother \& Unborn Baby Care of N. Tex., Inc. v. State, 749 S.W.2d 533, 536 (Tex. App. 1988) (holding that a CPC violated the Texas Deceptive Trade Practices Act); Fargo Women's Health Org. v. FM Women's Help \& Caring Connection, 444 N.W.2d 683, 683-84 (N.D. 1989) (holding that an abortion clinic could bring a false advertising claim for damages against a CPC), overruled by Trade 'N Post, L.L.C. v. World Duty Free Ams., Inc., 628 N.W.2d 707 (N.D. 2001).

74. See, e.g., Lewis v. Pearson Found., Inc., 908 F.2d 318 (8th Cir.), aff'd on reh'g en banc, 917 F.2d 1077 (8th Cir. 1990) (affirming by an equally divided court the district court's finding that women seeking abortions did not constitute a protected class for purposes of 42 U.S.C. § 1985(3)).

75. See, e.g., Boes v. Deschu, 768 S.W.2d 205, 208-09 (Mo. Ct. App. 1989) (holding that a woman's allegation that the CPC forced her to watch a graphic film featuring mutilated late term abortion fetuses before she could view the results of her pregnancy test sufficiently stated a claim for intentional infliction of emotional distress).

76. 410 U.S. 113 (1973).

77. Id. at 153 .

78. Id. at $163-64$.

79. Id. at $155-56$.

80. Id. at 155 .

81. Id. at $162-63$.

82. Id. at 164-65.

83. Id. at 164 . 
trimester, the state could regulate the abortion procedure. During the second trimester, the state could regulate, but not outlaw, abortions to protect maternal health. ${ }^{84}$ But during the third trimester, at which point the fetus is viable, the state could regulate and even prohibit abortions to promote its interest in potential life, except where necessary to save the woman's life. ${ }^{85}$

In Planned Parenthood of Southeastern Pennsylvania v. Casey, ${ }^{86}$ the Supreme Court reaffirmed "Roe's essential holding" that previability bans on abortion are unconstitutional. ${ }^{87}$ The Casey plurality, however, abandoned the strict scrutiny standard of review required by Roe and replaced it with the "undue burden" test. ${ }^{88}$ The undue burden test strikes down as unconstitutional an abortion regulation if it "has the purpose or effect of placing a substantial obstacle in the path of a woman seeking an abortion [previability]." 89 The plurality also rejected Roe's trimester framework to promote the state's interest in protecting potential life. ${ }^{90}$ The Court then applied this standard to the Pennsylvania statute at issue. The Court found that the twenty-four-hour waiting period, with emergency exceptions, and the requirement of parental consent for minors, with a judicial bypass exception, did not place a substantial obstacle in the path of a woman seeking abortion. ${ }^{91}$ With regard to the physician required disclosure, the Court concluded that while "the physician's First Amendment rights not to speak are implicated," this was "only as part of the practice of medicine, subject to reasonable licensing and regulation by the State" and no evidence was presented to demonstrate "that requiring a doctor to give the required information would amount to a substantial obstacle to a woman seeking an abortion." 92 The plurality, however, struck down the spousal notice requirement as unconstitutional because it placed an "undue burden on a woman's choice." 93

After Casey, the Court in Stenberg v. Carhart applied the undue burden test to strike down a Nebraska statute criminalizing so-called

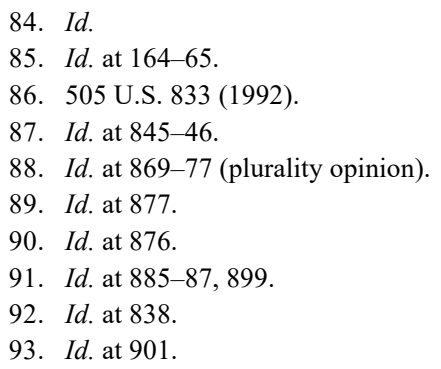


partial birth abortions. ${ }^{94}$ In particular, the Court reiterated the longstanding requirement that postviability abortion bans must contain an exception preserving maternal health - an exception the Nebraska statute lacked. ${ }^{95}$ Even if the statute had recognized this exception, however, the statute still created an undue burden because it applied broadly to not only the dilation and extraction procedure but also to the dilation and evacuation procedure, "thereby unduly burdening the right to choose abortion itself." 96

In dissent, Justice Kennedy criticized the majority for the lack of deference to state interests, ${ }^{97}$ but the majority emphasized that "a State may promote but not endanger a woman's health when it regulates the method of abortion." 98 Justice Kennedy added that the Court in Casey recognized "the physician's ability to practice medicine was 'subject to reasonable... regulation by the State' and would receive the 'same solicitude it receives in other contexts." "99 And in other contexts, Justice Kennedy argued, states are "entitled to make judgments where high medical authority is in disagreement." 100 Stenberg drew an important line, distinguishing medical regulations from laws that operate to burden a woman seeking an abortion by holding the Nebraska partial birth abortion ban unconstitutional.

In Gonzales v. Carhart, ${ }^{101}$ the Court assessed the constitutionality of the Partial-Birth Abortion Ban Act of 2003, a federal statute banning all dilation and evacuation procedures resulting in the delivery of "a living fetus." 102 Like the Nebraska statute at issue in Stenberg, the Act also contained no exception for safeguarding the woman's health. ${ }^{103}$ Nevertheless, Gonzales upheld the Act under the undue burden

94. 530 U.S. 914, 921 (2000). The term "partial birth abortion" was coined by the National Right to Life Committee, an anti-abortion group, to describe what the medical community calls the dilation and extraction (D \& X) procedure. Megan K. Donovan, D\&E Abortion Bans: The Implications of Banning the Most Common Second-Trimester Procedure, 20 GUTTMACHER POL'Y REV. 35, 36 (2017).

95. Stenberg, 530 U.S. at 921,930 (citing Casey, 505 U.S. at 879).

96. Id. at 930 (citing Casey, 505 U.S. at 874).

97. Id. at 969-70 (Kennedy, J., dissenting).

98. Id. at 931 (majority opinion) (citing Thornburgh v. Am. Coll. of Obstetricians \& Gynecologists, 476 U.S. 747, 768-69 (1986); Colautti v. Franklin, 439 U.S. 379, 400 (1979); Planned Parenthood of Cent. Mo. v. Danforth, 428 U.S. 52, 76 (1976); Doe v. Bolton, 410 U.S. 179, 191-92 (1973))

99. Id. at 969 (Kennedy, J., dissenting) (alteration in original) (quoting Casey, 505 U.S. at 884).

100. Id. at 970 .

101. 550 U.S. 124 (2007).

102. Id. at 142 .

103. See id. at 143. 
standard. ${ }^{104}$ In upholding the Act, Justice Kennedy, writing for the majority, adopted the position he argued for in his Stenberg dissent. ${ }^{105}$

The Court explained: "The question becomes whether the Act can stand when this medical uncertainty persists. The Court's precedents instruct that the Act can survive this facial attack. The Court has given state and federal legislatures wide discretion to pass legislation in areas where there is medical and scientific uncertainty." 106 In light of this uncertainty, Congress was entitled to deference in its factfinding that prohibiting dilation and evacuation procedures in this way did not pose any significant health risks, allowing the government's asserted interest to prevail. ${ }^{107}$ The Gonzales dissent criticized the majority for departing from Casey and Stenberg. ${ }^{108}$ Further, the dissent pointed to sound medical evidence in the record that undermined the majority's argument that there was any medical uncertainty. ${ }^{109}$

The inconsistent application of the undue burden test in Stenberg and Gonzales ${ }^{110}$ resulting from the Court's failure to provide a systematic methodology for determining when an "undue burden" on abortion exists, ${ }^{111}$ set the stage for the Court in Whole Woman's Health $v$. Hellerstedt to offer clarification. ${ }^{112}$ In Whole Woman's Health, the Court made clear that the undue burden test requires balancing the burdens and benefits of an abortion regulation to determine whether an undue burden

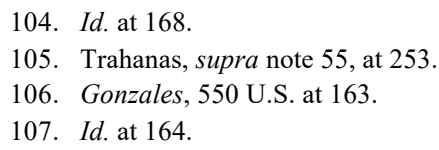

108. See id. at 170-71 (Ginsburg, J., dissenting) ("Today's decision is alarming. It refuses to take Casey and Stenberg seriously. It tolerates, indeed applauds, federal intervention to ban nationwide a procedure found necessary and proper in certain cases by the American College of Obstetricians and Gynecologists (ACOG). It blurs the line, firmly drawn in Casey, between previability and postviability abortions. And, for the first time since Roe, the Court blesses a prohibition with no exception safeguarding a woman's health.”).

109. Id. at 176 ("[T]he congressional record includes letters from numerous individual physicians stating that pregnant women's health would be jeopardized under the Act, as well as statements from nine professional associations, including ACOG, the American Public Health Association, and the California Medical Association, attesting that intact D \& E carries meaningful safety advantages over other methods.... No comparable medical groups have supported the ban.').

110. As a result, lower courts have also deeply struggled to apply the undue burden test. See Emma Freeman, Note, Giving Casey Its Bite Back: The Role of Rational Basis Review in Undue Burden Analysis, 48 HARV. C.R.-C.L. L. REV. 279 (2013) ("[T] that test remains murky. Consequently, courts have applied Casey inconsistently and unfaithfully, creating a tangled body of abortion precedent and rendering the undue burden standard insufficient to protect women's reproductive autonomy." (footnote omitted)).

111. Gillian E. Metzger, Unburdening the Undue Burden Standard: Orienting Casey in Constitutional Jurisprudence, 94 COLUM. L. REV. 2025 (1994).

112. Whole Woman's Health v. Hellerstedt, 136 S. Ct. 2292 (2016). 
exists. ${ }^{113}$ The Court applied this balance to find that two provisions of a Texas abortion law - an admitting-privileges provision and a surgicalcenter provision - did not "confer[] medical benefits sufficient to justify the burdens upon access [to abortion] that each impose[d]."114 These burdens, the Court concluded, posed "a substantial obstacle in the path of women seeking a previability abortion," and thus constituted an undue burden on the constitutional right to abortion. ${ }^{115}$

In finding that the admitting privileges requirement conferred no health benefits, the Court pointed to the district court's findings that, inter alia, (1) before the passage of the Texas law, abortion was "extremely safe," with "particularly low rates of serious complications and virtually no deaths occurring on account of the procedure," 116 and (2) when complications do occur, they rarely require hospital admission. ${ }^{117}$ Further, evidence in the record demonstrated that the admitting privileges requirement forced about half of Texas's abortion clinics to close. ${ }^{118}$ These closures translated into fewer abortion providers, significant wait times, and overcrowding at remaining clinics. ${ }^{119}$ The Court found no evidence in the record showing that the Texas law advanced the state's legitimate interest in protecting women's health.

Similarly, the surgical-center requirement provided no "better care or experience," ${ }^{120}$ because:

Nationwide, childbirth is 14 times more likely than abortion to result in death, but Texas law allows a midwife to oversee childbirth in the patient's own home. Colonoscopy, a procedure that typically takes place outside a hospital (or surgical center) setting, has a mortality rate 10 times higher than an abortion.... And Texas partly or wholly grandfathers ... about two-thirds of the facilities to which the surgicalcenter standards apply. But it neither grandfathers nor provides waivers for any of the facilities that perform abortions. These facts indicate that the surgical-center provision imposes "a requirement that

\footnotetext{
113. Id. at 2309 .

114. Id. at 2299.

115. Id.

116. Id. at 2302 (quoting Whole Woman's Health v. Lakey, 46 F. Supp. 3d 673, 684 (W.D. Tex. 2014)).

117. Id. at 2311 (citing Lakey, 46 F. Supp. 3d at 684).

118. Id.

119. Id. ("Record evidence [] supports the finding that after the admitting-privileges provision went into effect, the 'number of women of reproductive age living in a county ... more than 150 miles from a provider increased from approximately 86,000 to $400,000 \ldots$ and the number of women living in a county more than 200 miles from a provider from approximately 10,000 to 290,000." (alteration in original) (quoting Lakey, 46 F. Supp. 3d at 681)).

120. Id. at 2315 (citing Lakey, 46 F. Supp. 3d at 684).
} 
simply is not based on differences" between abortion and other surgical procedures "that are reasonably related to" preserving women's health, the asserted "purpos[e] of the Act in which it is found."121

The Court then explained that the surgical-center requirement was arbitrary, and there was no evidence to the contrary. ${ }^{122}$ The Court found the surgical-center requirement, like the admitting-privileges requirement, placed a "substantial obstacle to women seeking abortions," creating an "undue burden" on the constitutional right to choose abortion. ${ }^{123}$

\section{The Physician's Free Speech}

Free speech, a core tenet of American society, is vital to democratic self-governance and the search for truth. ${ }^{124}$ The First Amendment protects free speech to safeguard speakers and listeners alike from "government-compelled ideological speech."125 Government-compelled ideological speech in the medical field is especially dangerous because it "undermine[s] the integrity of the medical profession as a whole and its ability to advance scientific knowledge and social welfare." ${ }^{26}$ As seen in Stenberg, the Court at one point afforded no deference to legislatures that improperly interfere with the medical community when findings are medically uncertain because the uncertainty is a factor that signifies "the presence of risk, not its absence." 127

Regulations of medical providers' speech implicates free speech. The distinction between content-based and content-neutral regulations is central to First Amendment doctrine. ${ }^{128}$ Content-neutral regulations are

121. Id. (alteration in original) (citations omitted) (quoting Doe v. Bolton, 410 U.S. 179, 194 (1973)).

122. Id. at 2316 (citing Lakey, 46 F. Supp. 3d at 684).

123. Id. at 2318.

124. See Thornhill v. Alabama, 310 U.S. 88, 95 (1940) ("The safeguarding of these rights to the ends that men may speak as they think on matters vital to them and that falsehoods may be exposed through the processes of education and discussion is essential to free government... [and] to discover and spread political and economic truth."); Garrison v. Louisiana, 379 U.S. 64, 74-75 (1964) ("For speech concerning public affairs is more than self-expression; it is the essence of selfgovernment.").

125. Sarah Kramer, Not Your Mouthpiece: Abortion, Ideology, and Compelled Speech in Physician-Patient Relationships, 21 U. PA. J.L. \& Soc. CHANGE 1, 9 (2018).

126. Id. at 10 .

127. Stenberg v. Carhart, 530 U.S. 914, 937 (2000). But see Gonzales v. Carhart, 550 U.S. 124, 164 (2007).

128. See Elena Kagan, Private Speech, Public Purpose: The Role of Governmental Motive in First Amendment Doctrine, 63 U. CHI. L. REV. 413, 443 (1996) ("The distinction between contentbased and content-neutral regulations of speech serves as the keystone of First Amendment law."); 
subject to intermediate scrutiny, under which a content-neutral regulation is constitutional "if it advances important governmental interests unrelated to suppression of free speech and does not burden substantially more speech than necessary to further those interests." 129 Content-based regulations - regulations that "target speech based on its communicative content"- are generally subject to strict scrutiny, under which they are "presumptively unconstitutional and may be justified only if the government proves that they are narrowly tailored to serve compelling state interests." 130 Content-based regulations present a risk that the government is attempting to "suppress unpopular ideas or information or manipulate the public debate through coercion rather than persuasion," as opposed to advancing legitimate regulatory goals. ${ }^{131}$

Strict scrutiny, however, is not fatal in fact. ${ }^{132}$ At least two contentbased laws have survived strict scrutiny. ${ }^{133}$ One such case is Burson $v$. Freeman, in which the Court upheld a content-based restriction on soliciting votes and displaying campaign materials within 100 feet of polling place entrances, noting that this was "the rare case in which . . . a law survives strict scrutiny." 134 In finding that the State met strict scrutiny, the Court recognized "that the exercise of free speech rights conflicts with another fundamental right, the right to cast a ballot in an election free from the taint of intimidation and fraud." 135 In light of the conflict between these two rights, the Court held that "requiring solicitors to stand 100 feet from the entrances to polling places does not constitute an unconstitutional compromise." 136

Further, commercial speech is not subject to strict scrutiny. ${ }^{137}$

\footnotetext{
ERWin CHEMERINSKy, CONSTITUTIONAl LAW: PrinCIPLES AND POLICIES 932 (5th ed. 2015) ("The Supreme Court frequently has declared that the very core of the First Amendment is that the government cannot regulate speech based on its content.").

129. Holder v. Humanitarian Law Project, 561 U.S. 1, $26-27$ (2010) (quoting Turner Broad. Sys., Inc. v. FCC, 520 U.S. 180, 189 (1997)).

130. Reed v. Town of Gilbert, 135 S. Ct. 2218, 2226 (2015) (citing R.A.V. v. St. Paul, 505 U.S. 377, 395 (1992); Simon \& Schuster, Inc. v. Members of N.Y. State Crime Victims Bd., 502 U.S. $105,115,118(1991))$.

131. Turner Broad. Sys., Inc. v. FCC, 512 U.S. 622, 641 (1994).

132. See United States v. Playboy Entm't Grp., Inc., 529 U.S. 803, 846 (2000) (Breyer, J., dissenting) ("First Amendment standards are rigorous. ... Those standards at their strictest make it difficult for the Government to prevail. But they do not make it impossible for the Government to prevail.").

133. See Burson v. Freeman, 504 U.S. 191, 211 (1992) (plurality opinion); Holder, 561 U.S. at 40.

134. Burson, 504 U.S. at 211 (plurality opinion).

135. Id.

136. $I d$.

137. See Sorrell v. IMS Health Inc., 564 U.S. 552, 567 (2011) (“[T]he First Amendment does not
} 
Black's Law Dictionary defines commercial speech as "[c]ommunication (such as advertising and marketing) that involves only the commercial interests of the speaker and the audience, and is therefore afforded lesser First Amendment protection." 138 Since the Court departed from the Lochner approach, "ordinary economic and social legislation," including restrictions on commercial speech, "has been thought to raise little constitutional concern." "139

In Zauderer v. Office of Disciplinary Counsel, the Court differentiated between circumstances where the government compels disclosure in commercial speech "and outright prohibitions" on commercial speech. ${ }^{140}$ Philip Zauderer, an attorney, was reprimanded by the Office of Disciplinary Counsel of the Supreme Court of Ohio for his failure to include certain information in advertisements of his legal services. ${ }^{141}$ Zauderer's newspaper advertisement was intended to attract clients injured by the use of the Dalkon Shield Intrauterine Device. ${ }^{142}$ The advertisement stated that "[i]f there is no recovery, no legal fees are owed by our clients," but failed to note that clients may be liable for significant legal costs even if their lawsuit was unsuccessful, which violated an Ohio disciplinary rule requiring this disclosure. ${ }^{143}$ Zauderer argued that his First Amendment rights were violated by the government compelling this disclosure. ${ }^{144}$

The Court determined that the required disclosure did not violate the First Amendment because the disclosure did not suppress commercial speech, but rather only required "somewhat more information" than what an advertiser would "otherwise be inclined to present."145 The Court said that "disclosure requirements trench much more narrowly on an advertiser's interests than do flat prohibitions on speech, warnings or

prevent restrictions directed at commerce or conduct from imposing incidental burdens on speech."); see also Caroline Mala Corbin, Compelled Disclosures, 65 ALA. L. REv. 1277, 1291 (2014) ("Under current free speech doctrine, compelled speech, which is a content-based regulation, is subject to strict scrutiny unless it is commercial.").

138. Commercial Speech, BLACK's LaW Dictionary (11th ed. 2019)

139. Nat'l Inst. of Family \& Life Advocates v. Becerra, 138 S. Ct. 2361, 2381 (2018) (Breyer, J., dissenting).

140. 471 U.S. 626, 650 (1985). Suppression of commercial speech are subject to review under the test outlined in Central Hudson Gas \& Electric Co. v. Public Service Commission of New York, 447 U.S. 557 (1980). Id. at 638. "Commercial speech that is not false or deceptive and does not concern unlawful activities, however, may be restricted only in the service of a substantial governmental interest, and only through means that directly advance that interest." Id.

141. Id. at 630-33.

142. Id. at 630-31.

143. Id. at 631 .

144. Id. at 634 .

145. Id. at 650 
disclaimers might be appropriately required in order to dissipate the possibility of consumer confusion or deception." 146 The disciplinary rule only required Zauderer to include "purely factual and uncontroversial information about the terms under which his services will be available." "147 The Court held that disclosure requirements do not violate the First Amendment rights of an advertiser so long as the "disclosure requirements are reasonably related to the State's interest in preventing deception of consumers."148 Here, Ohio's requirement that the advertisement disclose the possibility of legal costs was reasonably related to Ohio's interest in protecting consumers from misleading advertisements. $^{149}$

This rationale was also at play in Justice Rehnquist's concurrence in Casey. ${ }^{150}$ Casey rejected the physician's free speech argument, explaining: "To be sure, the physician's First Amendment rights not to speak are implicated, but only as part of the practice of medicine, subject to reasonable licensing and regulation by the State." 151 The Court seemingly characterized the mandated disclosure as conduct a state may regulate "even though that conduct incidentally involves speech," avoiding a more exacting standard of review. ${ }^{152}$

However, the Supreme Court has held that commercial speech is limited to expression that "propose[s] a commercial transaction." 153 The doctor-patient relationship rises above a mere commercial transaction because "[p]hysician speech provides patients with expert information about medical conditions, procedures, risks, and appropriate courses of treatment."154 Further, "a physician's conversation with her client during the course of medical treatment is not an advertisement for a product or service, is not solely concerned with the sale of a product, and has little

\footnotetext{
146. Id. at 651 .

147. Id.

148. Id.

149. Id. at 652 .

150. See Planned Parenthood of Se. Pa. v. Casey, 505 U.S. 833, 977 (1992) (Rehnquist, J., concurring in the judgment in part and dissenting in part) ("[W]hen a state provides money to a private commercial enterprise, there is a legitimate public interest in informing taxpayers who the funds are benefiting and what services the funds are supporting." (citing Planned Parenthood of Se. Pa. v. Casey, 947 F.2d 682, 718 (3d Cir. 1991))).

151. Id. at 884 (citations omitted).

152. Nat'l Inst. of Family \& Life Advocates v. Becerra, 138 S. Ct. 2361, 2372 (2018) (citing Casey, 505 U.S. at 884).

153. Bd. of Trs. v. Fox, 492 U.S. 469, 473 (1989) (quoting Va. State Bd. of Pharmacy v. Va. Citizens Consumer Council, Inc., 425 U.S. 748, 762 (1976)).

154. See Jennifer M. Keighley, Physician Speech and Mandatory Ultrasound Laws: The First Amendment's Limit on Compelled Ideological Speech, 34 CARDOZO L. REV. 2347, 2367 (2013).
} 
to do with the physician's economic motivations."155

In Lowe v. SEC, Justice White noted in his concurring opinion that "the professional's speech is incidental to the conduct of the profession."156 Before NIFLA, some circuit courts invoked Justice White's concurrence as articulating a "professional speech doctrine," 157 which led to a circuit split over the recognition of "professional speech" as an independent category of speech subject to its own rules. ${ }^{158}$ The policy justification behind the professional speech doctrine as applied to the medical profession is centered on the special relationship established between medical providers and patients. ${ }^{159}$ The most important justification is that the health and safety of patients outweighs the benefits of political debate, ${ }^{160}$ making the marketplace of ideas theory a poor fit for regulation of physician speech. ${ }^{161}$ While recognized by some circuits, the professional speech doctrine was inconsistently applied and ultimately rejected in NIFLA.

\section{NIFLA v. Becerra}

In 2015, the California legislature passed the FACT Act to ensure that "[a]11 California women, regardless of income... have access to reproductive health services." 162 The California legislature enacted the FACT Act after it found "that a great number of California women were unaware of the existence of state-sponsored healthcare programs."163 The California legislature created the FACT Act to help low-income women find appropriate state-sponsored low-cost or free comprehensive

155. Id. at 2366

156. Lowe v. SEC, 472 U.S. 181, 232 (1985) (White, J., concurring).

157. Keighley, supra note 154, at 2368. See, e.g., Accountant's Soc'y of Va. v. Bowman, 860 F.2d 602, 604 (4th Cir. 1998) (arguing that Justice White's concurrence in Lowe "provides sound, specific guidelines for determining" when "a measure is no longer a regulation of a profession but a regulation of speech or of the press").

158. See Nat'l Inst. of Family \& Life Advocates v. Becerra (NIFLA), 138 S. Ct. 2361, 2371 (2018) (describing the various approaches taken by the circuit courts).

159. Pickup v. Brown, 740 F.3d 1208, 1227-28 (9th Cir. 2014) (noting that, outside the physician-patient relationship, "doctors are constitutionally equivalent to soapbox orators and pamphleteers, and their speech receives robust protection under the First Amendment").

160. See, e.g., Robert Post, Informed Consent to Abortion: A First Amendment Analysis of Compelled Physician Speech, 2007 U. ILL. L. REV. 939, 951 (2007).

161. See id. at 973-74.

162. A.B. 775, 2015-2016 Leg., Reg. Sess., § 1(a) (Cal. 2015).

163. Nat'l Inst. of Family \& Life Advocates v. Harris, 839 F.3d 823, 829 (9th Cir. 2016), rev'd sub nom. NIFLA, 138 S. Ct. 2361. 
family planning services. ${ }^{164}$ The legislature found that:

Millions of California women are in need of publicly funded family planning services, contraception services and education, abortion services, and prenatal care and delivery. In 2012, more than 2.6 million California women were in need of publicly funded family planning services. More than 700,000 California women become pregnant every year and one-half of these pregnancies are unintended. In 2010, 64.3 percent of unplanned births in California were publicly funded. Yet, at the moment they learn that they are pregnant, thousands of women remain unaware of the public programs available to provide them with contraception, health education and counseling, family planning, prenatal care, abortion, or delivery. ${ }^{165}$

The FACT Act required licensed and unlicensed clinics to disseminate certain information to patients. ${ }^{166}$ The FACT Act defined licensed clinics to include licensed primary care or specialty clinics that have the "primary purpose" of "providing family planning or pregnancyrelated services." 167 The FACT Act further required licensed clinics to satisfy at least two of the following six requirements:

(1) The facility offers obstetric ultrasounds, obstetric sonograms, or prenatal care to pregnant women.

(2) The facility provides, or offers counseling about, contraception or contraceptive methods.

(3) The facility offers pregnancy testing or pregnancy diagnosis.

(4) The facility advertises or solicits patrons with offers to provide prenatal sonography, pregnancy tests, or pregnancy options counseling.

(5) The facility offers abortion services.

(6) The facility has staff or volunteers who collect health information from clients. ${ }^{168}$

The FACT Act defined unlicensed clinics as a facility that is not licensed by the state, without "a licensed medical provider on staff or under contract," and that has the " "primary purpose' of 'providing

\footnotetext{
164. Cal. A.B. 775.

165. Id. $\S 1(\mathrm{~b})$.

166. See CAl. Health \& SAfETy CODE $\S 123472$ (West, Westlaw through ch. 3 of 2020 Reg. Sess.).

167. NIFLA, 138 S. Ct. at 2368-69 (quoting CAL. HEALTH \& SAFETY CODE § 123471(a)).

168. Id. (quoting CAL. HEALTH \& SAFETY CODE $§ 123471($ a)).
} 
pregnancy-related services." "169 The facility must also meet at least two of the following requirements:

(1) The facility offers obstetric ultrasounds, obstetric sonograms, or prenatal care to pregnant women.

(2) The facility offers pregnancy testing or pregnancy diagnosis.

(3) The facility advertises or solicits patrons with offers to provide prenatal sonography, pregnancy tests, or pregnancy options counseling.

(4) The facility has staff or volunteers who collect health information from clients. ${ }^{170}$

Licensed facilities were required to provide the following notice: "California has public programs that provide immediate free or low-cost access to comprehensive family planning services (including all FDAapproved methods of contraception), prenatal care, and abortion for eligible women. To determine whether you qualify, contact the county social services office...."171 Unlicensed clinics were required to provide the following notice: "This facility is not licensed as a medical facility by the State of California and has no licensed medical provider who provides or directly supervises the provision of services." ${ }^{172}$ The FACT Act exempted from the notice requirement federal clinics and clinics that were enrolled in Medi-Cal and participated in the Family Planning, Access, Care, and Treatment Program. ${ }^{173}$

In NIFLA v. Becerra, the National Institute of Family and Life Advocates, Pregnancy Care Center, and the Hope Clinic for Women (formerly the Fallbrook Pregnancy Resource Center) challenged the FACT Act on First Amendment grounds. ${ }^{174}$ Two of the three plaintiffs are nonprofit anti-abortion centers operating in California, while the National Institute of Family and Life Advocates is a parent organization comprised of centers. ${ }^{175}$ The plaintiffs brought suit against the California Attorney General, alleging that the FACT Act violated their right to free

169. Id. at 2370 (quoting CAL. HEALTH \& SAFETY CODE $§ 123471(\mathrm{~b})$ ).

170. Id. (quoting CAL. HEALTH \& SAFETY CODE $§ 123471$ (b)).

171. Id. at 2369 (quoting CAL. HEALTH \& SAFETY CODE $§ 123472(a)(1)$ ).

172. Id. at 2370 (quoting CAL. HEALTH \& SAFETY CODE $\S 123472(\mathrm{~b})(1)$ ).

173. Id. at 2369 (quoting CAL. HEALTH \& SAFETY CODE $§ 123471(\mathrm{c})$ ).

174. Id. at 2370 .

175. Nat'l Inst. of Family \& Life Advocates v. Harris, No. 15cv2277, 2016 WL 3627327, at *13 (S.D. Cal. Feb. 9, 2016). 
speech and freedom of religion under the First Amendment. ${ }^{176}$ The plaintiffs argued the disclosure requirements of the FACT Act required them "to recite government messages promoting abortion and deterring women from speaking with them." violations, the plaintiffs filed a motion for a preliminary injunction to enjoin enforcement of the FACT Act until adjudication of the claims. ${ }^{178}$

The United States District Court for the Southern District of California denied the preliminary injunction, ${ }^{179}$ and the Ninth Circuit affirmed. ${ }^{180}$ The Ninth Circuit first explained that the Supreme Court did not establish a standard of review to apply when it upheld abortionrelated disclosure laws in Casey and Gonzales. ${ }^{181}$ The Ninth Circuit therefore turned to its own precedent recognizing a continuum of professional behavior, with "public dialogue" on one end, where the First Amendment is most protected, and "professional conduct" at the other end, where it is least protected. ${ }^{182}$ The Ninth Circuit held the FACT Act fell "in the middle of the continuum," within the professional-client relationship where "the purpose... is to advance the welfare of the clients, rather than to contribute to public debate," and intermediate scrutiny thus applied. ${ }^{183}$ It found that "the professional nature of the licensed clinics' relationship with their clients extends beyond the examining room," and the nonprofit status of the clinics did not change the fact that the clinics were "professional," because the clinics had entered the marketplace as pregnancy clinics. ${ }^{184}$ The Ninth Circuit held that the licensed notice survived intermediate scrutiny because it advanced California's substantial interest in ensuring California citizens have access to state-funded family-planning services and was narrowly drawn to inform pregnant women facing time-sensitive choices. ${ }^{185}$ The unlicensed notice survived any level of scrutiny, as the Ninth Circuit found the statute was narrowly tailored to advance California's compelling interest in providing accurate information about the licensing

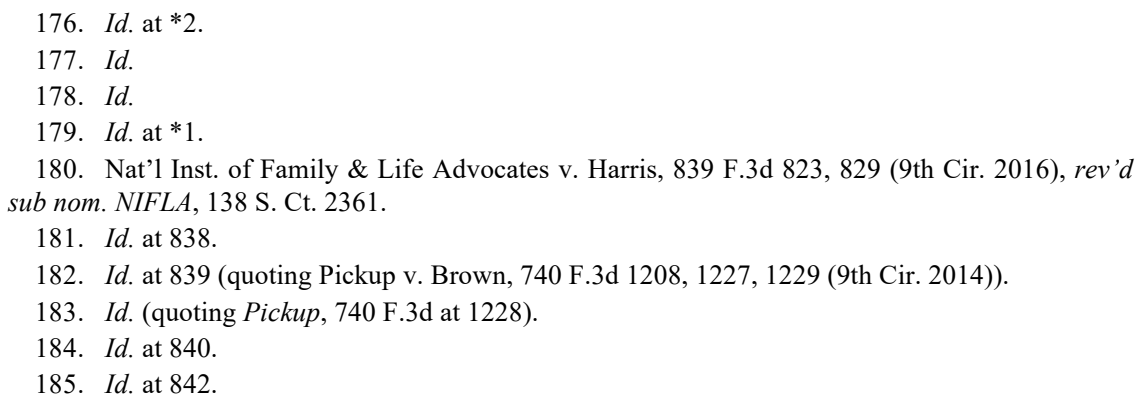


status of clinics. ${ }^{186}$

The Supreme Court reversed and held that both of the FACT Act's notice requirements were unconstitutional infringements on the CPCs' speech. ${ }^{187}$ Justice Thomas, writing for the majority, found that the FACT Act was a content-based regulation of speech, and was thus presumptively unconstitutional-justified only if it survived strict scrutiny. ${ }^{188}$ The Court rejected the Ninth Circuit's public speech continuum and declined to recognize "professional speech" as a separate category of speech meriting less First Amendment protection. ${ }^{189}$ Instead, the majority declared that only two exceptions exist to the general rule that "content-based regulations of speech are subject to strict scrutiny" "190: (1) "laws that require professionals to disclose factual, noncontroversial information in their "commercial speech"" under Zauderer $^{191}$ and (2) laws that regulate "professional conduct" that "incidentally involves speech" under Casey. ${ }^{192}$

The Court held that the licensed notice fell into neither exception. Distinguishing Zauderer, the Court found that the licensed notice required "these clinics to disclose information about state-sponsored services," not services the clinic provides, "including abortion, anything but an 'uncontroversial' topic."193 Casey also did not apply, said the Court, because the licensed notice was "not an informed-consent requirement or any other regulation of professional conduct." 194 It was "not tied to a procedure at all" and "applie[d] to all interactions between a covered facility and its clients, regardless of whether a medical procedure [wa]s ever sought, offered, or performed."195 The licensed notice was therefore a regulation of "speech as speech" rather than of "professional conduct.". "The Court held that when neither exception applied, content-based regulations are subject to strict scrutiny. ${ }^{197}$

The Court stated that even if there were reason to treat professional speech as a "unique category that is exempt from ordinary First

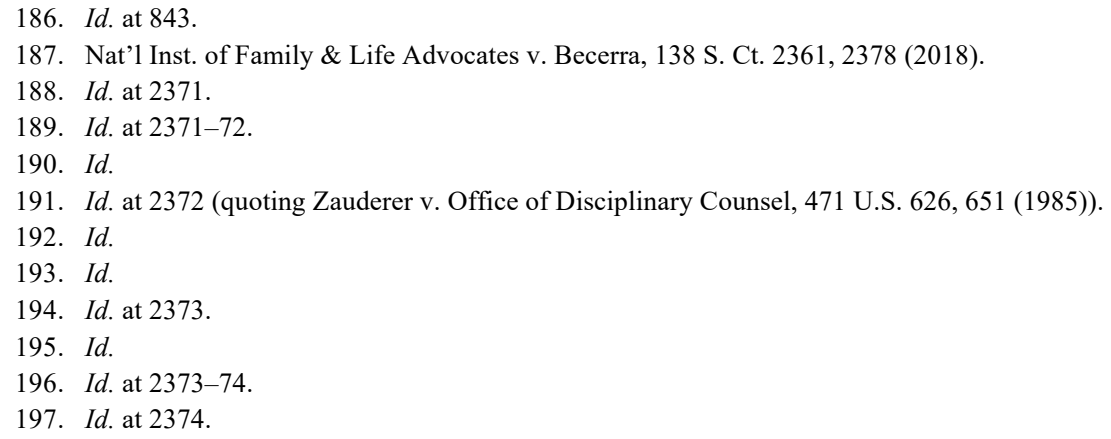


Amendment principles," the licensed notice would fail even intermediate scrutiny, as it was not "sufficiently drawn" to promote California's interest in providing low-income women with information about the availability of state-sponsored services. ${ }^{198}$ The Court found the licensed notice "wildly underinclusive" because it applied only to federal clinics and clinics that were part of the state health care program. ${ }^{199}$ Further, California could have used a "public-information campaign" to inform women of their services. ${ }^{200}$

The Court then held that the unlicensed notice would fail even if the Zauderer standard applied because California failed to show that the unlicensed notice was not "unjustified or unduly burdensome."201 In deciding the unlicensed notice was unjustified, Justice Thomas concluded that California's only justification-_ensuring that pregnant women know when they are receiving medical care from licensed professionals"-was "purely hypothetical." "202 The Court also found the unlicensed notice underinclusive, and therefore unduly burdensome, because it applied only to facilities that provide pregnancy-related services, excluding facilities that that provide nonprescription contraceptives. $^{203}$ The unlicensed notice was also unduly burdensome because it included requirements "to call attention to the notice... in as many as 13 different languages," which would drown out the CPC's own advertisements. $^{204}$

Justice Breyer dissented, joined by Justices Ginsburg, Sotomayor, and Kagan. Criticizing the Court for recognizing only two narrow exceptions to the general rule that strict scrutiny applies to content-based regulations, the dissent argued that the Court's approach threatens "virtually every disclosure law" in a way unseen since the Lochner era because "much, perhaps most, human behavior takes place through speech" and "much, perhaps most, law regulates that speech in terms of its content." 205 Justice Breyer stated that "[u]sing the First Amendment to strike down economic and social laws that legislatures long would

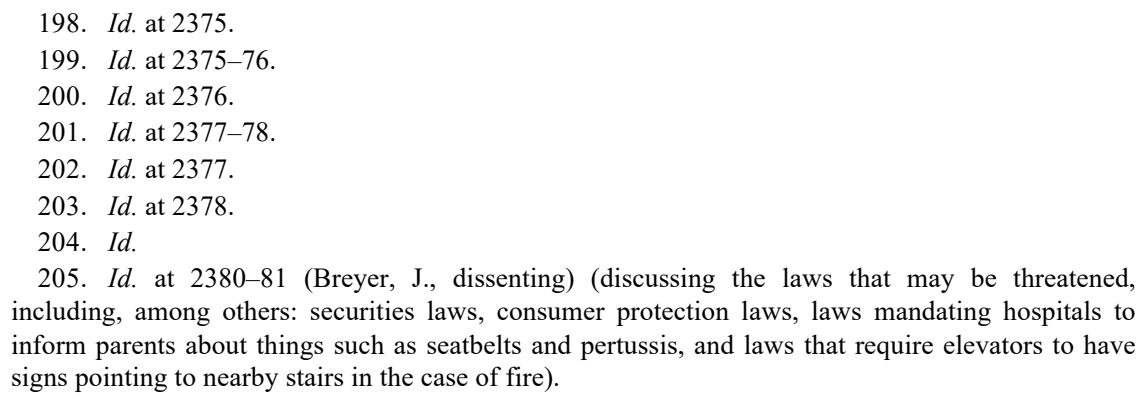
including, among others: securities laws, consumer protection laws, laws mandating hospitals to inform parents about things such as seatbelts and pertussis, and laws that require elevators to have signs pointing to nearby stairs in the case of fire). 
have thought themselves free to enact will, for the American public, obscure, not clarify, the true value of protecting freedom of speech." ${ }^{206}$ This sentiment is echoed in Part III.

Justice Breyer found Casey controlling. ${ }^{207}$ "If a State can lawfully require a doctor to tell a woman seeking an abortion about adoption services," he asked, "why should it not be able, as here, to require a medical counselor to tell a woman seeking prenatal care or other reproductive healthcare about childbirth and abortion services?"208 Justice Breyer rejected the majority's distinction between the informed consent law at issue in Casey and the licensed notice as "lack[ing] moral, practical, and legal force." ${ }^{209}$ He noted that the licensed clinics all included medical professionals providing pregnancy-related services and required such medical professionals to disclose information helpful to granting informed consent, and thus similarly regulated professional conduct of the practice of medicine. ${ }^{210}$

Further, Justice Breyer cited Zauderer for the proposition that heightened scrutiny is inapplicable to the licensed notice, arguing the question instead should be "whether the disclosure requirements were 'reasonably related to the State's interest in preventing deception of consumers" because the information "is related to the services that licensed clinics provide." ${ }^{211}$ He explained that the licensed disclosure would not warrant heightened scrutiny in this instance because it requires the disclosure of purely factual information regarding state resources. ${ }^{212}$ As for the unlicensed disclosure, Justice Breyer noted the majority's approach was also "incompatible with Zauderer" because the standard is not whether the "State's interest is purely hypothetical" - a standard applicable to speech restrictions, not disclosures - rather, the standard is whether the disclosure requirement is "reasonably related to the State's interest." 213 Even so, he said, "[t]here is no basis for finding the State's interest hypothetical," noting that the California legislature "heard that information-related delays in qualified healthcare negatively affect

\footnotetext{
206. Id. at 2383 .

207. Id. at 2385 (noting that Casey upheld a "requirement that the doctor must inform his patient about where she could learn how to have the newborn child adopted (if carried to term) and how she could find related financial assistance" (citing Planned Parenthood of Se. Pa. v. Casey, 505 U.S. 833, $881(1992)))$.

208. $I d$.

209. Id.

210. Id. at $2385-86$.

211. Id. at 2387 (quoting Zauderer v. Office of Disciplinary Counsel, 471 U.S. 626, 651 (1985)).

212. Id.

213. Id. at 2387-90 (quoting Zauderer, 471 U.S. at 651).
} 
women seeking to terminate their pregnancies as well as women carrying their pregnancies to term, with delays in qualified prenatal care causing life-long health problems for infants." ${ }^{214}$ Finally, legislatures can counteract these impacts "by a general rule, even though in particular instances there might be no actual deception or misstatement." 215

\section{ANALYSIS}

It is necessary to examine the NIFLA majority's reasoning and synthesize the rule it set forth because there is a double standard at play. On remand, the Ninth Circuit must now review the case under strict scrutiny, and while strict scrutiny is not necessarily fatal in fact, this Part argues that the FACT Act fails strict scrutiny. This Part also argues that NIFLA finally gives physicians a leg to stand on to invalidate statemandated compelled speech informed consent disclosures in the abortion context. First, this Part analyzes NIFLA's holding and argues that the FACT Act is not narrowly tailored to pass strict scrutiny. Next, it discusses NIFLA's power to invalidate paternalistic informed consent laws regulating abortion, and then applies the NIFLA standard to Kansas, South Dakota, and Indiana abortion informed consent statutes, which provide clear examples of unconstitutional abortion regulations under the guise of informed consent. Lastly, this Part concludes by redrafting a section of the FACT Act that would likely fit within the exception recognized by the majority that allows for the regulation of professional conduct that incidentally involves speech.

\section{A. NIFLA Allows CPCs to Play Doctor}

NIFLA is problematic because it gives CPCs a green light to offer medical advice free of state regulation. The Court in NIFLA held that the CPCs were likely to succeed on the merits, ${ }^{216}$ signaling the lower court to issue a preliminary injunction. NIFLA potentially signifies the end of a commercial speech exception to strict scrutiny review under the First Amendment. ${ }^{217}$ But, perhaps the upside of NIFLA is that it may lead to the end of paternalistic informed consent statutes in the context of

\footnotetext{
214. Id. at 2390 .

215. Id.

216. Id. at 2378.

217. Corey L. Andrews, The Dog That Didn't Bark in the Night: SCOTUS's NIFLA v. Becerra and The Future of Commercial Speech, FoRBES (July 5, 2018, 11:02 AM), https://www.forbes.com /sites/wlf/2018/07/05/the-dog-that-didnt-bark-in-the-night-scotuss-nifla-v-becerra-and-the-future-of -commercial-speech/\#64ef8ae13ddc [https://perma.cc/FY64-KNYA].
} 
abortion. Under the standard set forth in NIFLA, many, if not all, abortion informed consent laws are unconstitutional.

The Court applied a standard that is inconsistent with free speech and informed consent case law. ${ }^{218}$ By providing only two narrow exceptions to the general rule that content-based regulations are subject to strict scrutiny analysis, NIFLA departed from Supreme Court precedent. This has left a need for the adoption of a rule that not remains faithful to Supreme Court precedent and protects women seeking an abortion. ${ }^{219}$ As the dissent in NIFLA emphasized, stare decisis requires consistency between the Court's precedent and NIFLA. ${ }^{220}$

Possible reasons for the distinction between Casey and NIFLA could be the subject of the disclosures, the types of services provided, or the fact that CPCs and abortion clinics employ different medical providers. The distinction, however, cannot be because of the subject of the disclosure. The contested disclosures in NIFLA "concern[ed] speech related to abortion." 221 The Court in Casey similarly assessed the constitutionality of disclosure requirements related to reproductive health. ${ }^{222}$ However, the Court has never heard a case on the constitutionality of informed consent requirements outside the context of contraception and abortion. As Justice Breyer argued in his NIFLA dissent, Casey should have controlled because "there is no convincing reason to distinguish between information about adoption and information about abortion in this context."223

One could logically conclude the dissenters are right: there is no reason to treat the FACT Act differently than other informed consent statutes, and therefore Casey should control. Another rational conclusion is that CPCs should receive different treatment than other medical providers. Despite the claims presented on their websites ${ }^{224}$ and the occasional presence of licensed medical professionals on staff, ${ }^{225}$ perhaps

218. Compare Planned Parenthood of Se. Pa. v. Casey, 505 U.S. 833, 881-83 (1992) (upholding a law requiring medical providers to provide anti-abortion information to women seeking abortions), with NIFLA, 138 S. Ct. at 2373 (finding the FACT Act's licensed notice requirement was different from the law at issue in Casey and required a heightened level of scrutiny).

219. See NIFLA, 138 S. Ct. at 2381-83 (Breyer, J., dissenting).

220. See id. at 2381-82.

221. Id. at 2383 .

222. See Casey, 505 U.S. at 844.

223. NIFLA, 138 S. Ct. at 2385 (Breyer, J., dissenting)

224. See, e.g., About NIFLA, supra note 66 (advertising "medical" services); see also Our Services, HOPE ClINIC FOR WOMEN, http://www.fallbrookprc.com/Our-Services [https://perma.cc /RY33-UPTJ] (last visited Apr. 3, 2020) (advertising services such as pregnancy tests and ultrasounds and describing common symptoms of pregnancy).

225. Bryant, supra note 33 . 
CPCs are not medical providers at all, but proselytizing anti-abortion activists dressed in doctors' clothing. From this perspective, the FACT Act does not provide informed consent disclosure requirements.

The lack of discovery allowed the justices to ignore that the CPC petitioners are engaged in medical procedures, screenings, methods of treatment, counseling, or any other medical intervention. ${ }^{226}$ Because NIFLA dealt with a preliminary injunction, ${ }^{227}$ discovery had not yet occurred, and there is no way to tell if the majority's reasoning would have differed in light of the likelihood that the CPCs are practicing medicine. However, it is possible to examine the general practices of the CPC petitioners to predict what standard would have applied to the speech regulating professional conduct on the facts of the case in light of Supreme Court precedent.

On remand, the petitioners' arguments could fail in the Ninth Circuit because their constitutional concerns could be overcome by controlling Supreme Court precedent that may be invoked after discovery if discovery leads to the conclusion that the medical providers in licensed CPCs are engaged in the professional conduct or commercial speech. In NIFLA, the petitioners argued that their speech was not commercial because: (1) they are nonprofits; (2) their services are free; and (3) other courts have found that CPCs are not commercial in nature and therefore not subject to commercial speech regulations. ${ }^{228}$ A profit motive alone, however, is not dispositive of whether speech is commercial speech. ${ }^{229}$ The "content and context" 230 of commercial speech "does no more than propose a commercial transaction," ${ }^{231}$ and courts must examine "the

226. Justice Kennedy refused to look online at the CPCs' websites to discover the services they purport to provide because that information was beyond the record. See Transcript of Oral Argument at 22, NIFLA, 138 S. Ct. 2361 (No. 16-1140).

227. See NIFLA, 138 S. Ct. at 2370.

228. Nat'l Inst. of Family \& Life Advocates v. Harris, No. 15cv2277, 2016 WL 3627327, at *7 (S.D. Cal. Feb. 9, 2016).

229. See, e.g., Bolger v. Youngs Drug Prods. Corp., 463 U.S. 60, 66-68 (1983) (finding that mailings sent out by the defendant constituted commercial speech when they were advertisements that referenced specific products even though they also included information on public health issues); Greater Balt. Ctr. for Pregnancy Concerns, Inc. v. Mayor \& City Council of Balt., 721 F.3d 264, 285 (4th Cir. 2013) (noting that, from Bolger v. Youngs Drug Products Corp., circuit courts have identified "three factors to consider in deciding if speech is commercial: (1) is the speech an advertisement; (2) does the speech refer to a specific product or service; and (3) does the speaker have an economic motivation for the speech" (quoting U.S. Healthcare, Inc. v. Blue Cross of Greater Phila., 898 F.2d 914, 933 (3d Cir. 1990))). But see Harris v. Quinn, 573 U.S. 616, 648 (2014) (defining commercial speech as speech that merely proposes a transaction).

230. See Keighley, supra note 154, at 2366.

231. Va. State Bd. of Pharmacy v. Va. Citizens Consumer Council, Inc., 425 U.S. 748, 762 (1976). 
nature of the speech taken as a whole and the effect of the compelled statement thereon." 232

Since the Lochner era, the Court has given deference to state regulations of the medical profession. ${ }^{233}$ States may impose reasonable conditions on the practice of medical and "[m]edical professionals do not, generally speaking, have a right to use the Constitution as a weapon allowing them rigorously to control the content of those reasonable conditions." ${ }^{234}$ As the Court explained in its 1926 Lambert v. Yellowley decision, "there is no right to practice medicine which is not subordinate to the police power of the states."235 Lambert utilized only a rational basis standard of review, ${ }^{236}$ which the FACT Act would pass because not only does California have a legitimate interest in promoting the health of women, it arguably has a compelling one, much like Pennsylvania did in Casey. ${ }^{237}$

It is true, however, that the doctor-patient relationship is not truly commercial in nature. ${ }^{238}$ Medical providers engage in commercial speech when placing an advertisement in a local newspaper or running a television commercial for a cancer treatment center, ${ }^{239}$ but when speech takes place in a clinical setting, like in a discussion to obtain informed consent or a disclosure of the alternative services offered by the state, the communication transcends commercial speech. ${ }^{240}$ NIFLA, however, ignored the context of the FACT Act disclosures. CPCs often present themselves as medical clinics, and their medical providers, or persons playing doctor, purport to advise women of their medical options. This makes the holding troubling, particularly given that the Court upheld the

232. Riley v. Nat'l Fed'n of the Blind of N.C., Inc., 487 U.S. 781, 796 (1988).

233. NIFLA, 138 S. Ct. at 2382 (Breyer, J., dissenting). But see Sorrell v. IMS Health Inc., 564 U.S. 552, 567, 580 (2011) (holding that a Vermont law restricting the use of pharmacy records for marketing purposes "imposes more than an incidental burden on protected expression" because it "is directed at certain content and is aimed at particular speakers").

234. NIFLA, $138 \mathrm{~S}$. Ct. at 2382 (Breyer, J., dissenting).

235. 272 U.S. $581,596(1926)$.

236. Id. at $589,594-95$.

237. See Planned Parenthood of Se. Pa. v. Casey, 505 U.S. 833, 884-86 (1992) (plurality opinion).

238. See Keighley, supra note 154, at 2365 (arguing that doctor-patient speech "does not qualify" as commercial speech). But see Corbin, supra note 137, at 1286 (considering Zauderer's holding to be general enough to apply to physicians and nonprofits and stating that, "[c]learly, the commercial-noncommercial dichotomy overlooks speech that falls in between, including speech by individual professionals and advertising by nonprofit entities").

239. See Zauderer v. Office of Disciplinary Counsel, 471 U.S. 626, 629-30 (1985) (examining the commercial nature of an advertisement in the context of legal services).

240. Keighley, supra note 154, at 2366 (“[A] physician's speech during the provision of medical care falls outside of this definition [of commercial speech]."). 
inverse of the required disclosures as a constitutional informed consent law in Casey. ${ }^{241}$ The Court argued that the contrasting holdings in Casey and NIFLA resulted from the different standards of review the facts necessitated. In Casey, the Court analyzed the physician's speech under the rational basis test. ${ }^{242}$ In contrast to the strict scrutiny standard of review applied in NIFLA, the rational basis hurdle is inherently easier for states to overcome when all they need to assert is that the content-based regulation of speech on physicians offering abortion procedures is reasonably designed to promote the state's interest in preserving potential life.

The lack of discovery in NIFLA ${ }^{243}$ allowed the majority to ignore that CPCs are engaged in medical procedures, screenings, methods of treatment, counseling, or any other medical intervention. ${ }^{244}$ These facts, however, are likely to be found as the litigation proceeds. CPCs are likely engaged in the practice of medicine, especially those operating as licensed clinics. ${ }^{245}$ National Institute of Family and Life Advocates asserts on its own website that their CPCs are medical clinics. ${ }^{246}$ Hope Clinic for Women, the unlicensed CPC petitioner in NIFLA, lists medical services the clinic provides, which include: (1) verifying pregnancy; (2) determining the gestational age of the fetus; and (3) providing "facts about abortion and the documented abortion risk factors." 247 The CPC, however, admits on its own website that pregnancy can only be diagnosed by a licensed physician. ${ }^{248}$ Pregnancy Care Center (doing business as Pregnancy Care Clinic), a licensed health care facility, also (1) verifies pregnancy; (2) conducts ultrasound exams; (3) offers health

241. Nat'l Inst. of Family \& Life Advocates v. Becerra, 138 S. Ct. 2361, 2386-87 (2018) (Breyer, J., dissenting).

242. Casey, 505 U.S. at 884,880 (plurality opinion).

243. NIFLA, $138 \mathrm{~S}$. Ct. at 2370.

244. Justice Kennedy refused to look online at the CPCs' websites to discover the services they purport to provide because that information was beyond the record. See Transcript of Oral Argument at 22, NIFLA, 138 S. Ct. 2361 (No. 16-1140).

245. See About NIFLA, supra note 66 ("NIFLA now represents more than 1,500 pro-life pregnancy centers across the country. Of that number, over 1,200 operate as licensed medical clinics.... NIFLA has two key programs to support compliance and conversion for pregnancy centers. The Life Choice Project (TLC) offers a step-by-step conversion program, while NIFLA's Institute in Limited Obstetric Ultrasound equips medical and management personnel in the legal requirements for operating a medical clinic.”).

246. See id.

247. Our Services, supra note 224.

248. Id. The Hope Clinic for Women carefully disclaims "only a licensed physician can diagnose pregnancy," and explains that "[i]f you have a positive pregnancy test our staff may schedule a limited OB ultrasound appointment for you with the mobile medical clinic that comes to $\mathrm{HCW}$ on a regular basis." Id. "The staff at HCW will help you understand your options." Id. 
provider consultations; (4) makes medical referrals; and (5) offers consultations regarding family planning and sexually transmitted diseases. ${ }^{249}$ By offering the same services as medical providers, CPCs as licensed and unlicensed facilities walk right up to the line and intentionally blur what constitutes medical care.

Assuming that the two compelled disclosures in Casey and NIFLA are virtually indistinguishable, it is unnecessary to examine the licensed and unlicensed disclosures separately. The analysis of each disclosure is not distinct because the focus to determine if the center is engaged in the practice of medicine is what the CPCs are doing and saying-or not doing and not saying - which does not change drastically between the CPCs with medical licenses and those without. ${ }^{250}$ Examining "the nature of the speech taken as a whole and the effect of the compelled statement," 251 it is evident that CPCs are either likely engaging in the practice of medicine or acting as if they are engaged in the practice of medicine. $^{252}$

Because CPCs either do practice or appear to practice medicine, the Ninth Circuit should apply the commercial speech exception to strict scrutiny recognized in NIFLA on remand. Supreme Court precedent since the Lochner era, which consistently gives deference to state regulations of medical practice, ${ }^{253}$ should apply to the regulation of CPCs as well. The conclusion that CPCs practice medicine, which was arguably unavailable to the Supreme Court without discovery, may be available to the Ninth Circuit. ${ }^{254}$ However, the Ninth Circuit will likely apply strict scrutiny in light of the NIFLA majority's determination that the petitioners were likely to succeed on the merits and that it was not persuaded an exception to strict scrutiny analysis applied. ${ }^{255}$

249. Services, PREGNANCY CARE CLINIC, https://www.unplannedparenthood.org/services/ [https://perma.cc/ACY6-3EUM] (last visited May 11, 2020).

250. See Alice X. Chen, Note, Crisis Pregnancy Centers: Impeding the Right to Informed Decision Making, 19 CARDOZO J.L. \& GENDER 933, 935-36 (2013) (listing the practices of licensed and unlicensed CPCs).

251. Riley v. Nat'l Fed'n of the Blind of N.C., Inc., 487 U.S. 781, 796 (1988).

252. See Chen, supra note 250, at 948-49.

253. See, e.g., Williamson v. Lee Optical of Okla., Inc., 348 U.S. 483, 486-88 (1955) (upholding state statute regulating opticians).

254. Justice Sotomayor went beyond the record and looked at the websites of the petitioners before concluding that they were engaged in the practice of medicine, and Justice Kennedy mentioned the inability of the justices to conduct outside discovery. See Transcript of Oral Argument at 18-22, Nat'l Inst. of Family \& Life Advocates v. Becerra, 138 S. Ct. 2361 (2018) (No. 16-1140).

255. NIFLA, 138 S. Ct. at 2375 (recognizing that the notice would not "survive even intermediate scrutiny"). 


\section{B. The FACT Act Fails Strict Scrutiny Because It Is Not Narrowly Tailored}

The NIFLA battle is not over. Even if strict scrutiny applies, the FACT Act may survive, despite the Court's ruling that the petitioners were likely to succeed on the merits. ${ }^{256}$ The FACT Act will survive strict scrutiny if California can show (1) that the government's interest is compelling and (2) that the statute is narrowly tailored as the least restrictive means to accomplish the state's regulatory goal. ${ }^{257}$ Surviving strict scrutiny is rare, however, and unlikely here, given the Supreme Court's decision.

California has a compelling interest at stake. The state, in enacting the FACT Act, sought to remove obstacles in the path of a woman seeking reproductive health care. ${ }^{258}$ But the FACT Act should fail strict scrutiny because it is not narrowly tailored to achieve California's regulatory goals. There are alternatives California may impose that would be less burdensome to the speaker, ${ }^{259}$ such as promulgating a truth-in-advertising statute that applies to medical clinics and then prosecuting those who engage in misleading or false advertising practices. $^{260}$ Another alternative is to provide the information to lowincome women through advertising campaigns that offer free pregnancy diagnoses by licensed physicians participating in Medi-Cal with the intent to identify eligible women to enroll in the state's program. In

256. See, e.g., Burson v. Freeman, 504 U.S. 191, 211 (1992) (noting that a case rarely survives strict scrutiny, but the two conflicting fundamental rights at issue made the survival of strict scrutiny possible); Holder v. Humanitarian Law Project, 561 U.S. 1, 27-28, 40 (2010) (finding a federal statute survived strict scrutiny analysis).

257. Burson, 504 U.S. at 198.

258. This argument does not appear in the briefs filed by the respondents, however amicus briefs for the respondents have detailed this argument and other compelling interests that would allow the Reproductive FACT Act to pass strict scrutiny. One amicus brief for the respondents argued that California has a "compelling interest in ensuring women have access to comprehensive and timely healthcare information and services in the face of deception." Brief for Reproductive Rights, Civil Rights, and Social Justice Organizations as Amici Curiae Supporting Respondents at 2, NIFLA, 138 S. Ct. 2361 (No. 16-1140), 2018 WL 1168249. Another amicus brief for the respondents argued that California has a compelling interest in mitigating the prima facie unethical medical conduct of the Pregnancy Care Clinic and that the Reproductive FACT Act survives strict scrutiny based on this compelling state interest. See Brief of American Medical Association as Amicus Curiae in Support of Respondents at 14, NIFLA, 138 S. Ct. 2361 (No. 16-1140), 2018 WL 1156609.

259. NIFLA, $138 \mathrm{~S}$. Ct. at 2376 (discussing the "disconnect between [the FACT Act's] stated purpose and its actual scope" and suggesting less burdensome alternatives such as a publicinformation campaign or posting information on public property near $\mathrm{CPCs}$ ).

260. This may be problematic as applied to unlicensed CPCs, however, as there is debate surrounding whether these centers are medical clinics and if the centers' speech is commercial. See Campbell, supra note 34, at 99-100. 
conclusion, while California's interest is compelling, it is likely not narrowly tailored, and therefore will likely fail strict scrutiny, ${ }^{261}$ especially if the Ninth Circuit relies on Justice Thomas's reasoning in NIFLA.

\section{NIFLA's Power to Invalidate Current "Informed Consent" Abortion Laws}

Exempting paternalistic abortion-specific informed consent laws that have no basis in science or medicine from strict scrutiny analysis but subjecting state laws that regulate misleading and deceptive CPC practices through mandatory disclosure requirements to strict scrutiny is unjust and leaves many women uninformed of their options. To suggest that the voice of one set of medical providers is more important than another's establishes that only one view is suitable, which is exactly the type of bias the First Amendment is supposed to protect against. ${ }^{262}$ In a world where states continue to restrict access to abortion, ${ }^{263} \mathrm{CPCs}$ should not be able to hide behind the First Amendment for protection while playing doctor with marginalized women ${ }^{264}$ who are in need of accurate medical information and medical care free of moral judgment.

The purposes of laws like the FACT Act are to protect marginalized women from being taken advantage of, ${ }^{265}$ persuaded to leave their due

261. The Ninth Circuit, however, determined the disclosure was narrowly tailored and the FACT Act survived any standard of review. See Nat'l Inst. of Family \& Life Advocates v. Harris, 839 F.3d 823, 829 (9th Cir. 2016) ("The licensed notice regulates professional speech, subject to intermediate scrutiny, which it survives. The unlicensed notice survives any level of review."), rev'd sub nom. NIFLA, 138 S. Ct. 2361.

262. See NIFLA, 138 S. Ct. at 2385 (Breyer, J., dissenting) ("If a State can lawfully require a doctor to tell a woman seeking an abortion about adoption services," as in Casey, "why should it not be able, as here, to require a medical counselor to tell a woman seeking prenatal care or other reproductive healthcare about childbirth and abortion services?').

263. See An Overview of Abortion Laws, GUTTMACHER INST., https://www.guttmacher.org/state -policy/explore/overview-abortion-laws [https://perma.cc/EJQ6-RLRM] (last visited Mar. 29, 2020) (stating that "45 states allow individual health care providers to refuse to participate in an abortion," "42 states allow institutions to refuse to perform abortions," and " 43 states prohibit abortions, generally except when necessary to protect the woman's life or health, after a specified point in pregnancy"). Despite these restrictions, about one fourth of American women will have had an abortion by the time they have reached forty-five. See Abortion Is a Common Experience for U.S. Women, Despite Dramatic Declines in Rates, GUTTMACHER InST. (Oct. 19, 2017), https:// www.guttmacher.org/news-release/2017/abortion-common-experience-us-women-despite-dramaticdeclines-rates [https://perma.cc/K29U-EGQK].

264. Campbell, supra note 34 , at 76 ("CPCs specifically target low-income communities, minority populations, and places with young, vulnerable women, like high schools and colleges. CPCs believe their efforts are best suited for these demographics because they have higher rates of pregnancy and abortion, and thus, are more susceptible to CPC practices." (footnotes omitted)).

265. Chen, supra note 250, at 944 ("The purposes of these ordinances are to protect public 
process rights behind, and forced to face the real life medical consequences of pregnancy, labor, and delivery without fully understanding their rights or the medical risks and benefits of all options. ${ }^{266}$ The goal of providing women with information is similar to the stated purpose of the law at issue in Casey, which also had the purpose of informing women. ${ }^{267}$

Justice Breyer's NIFLA dissent highlighted the similarities between the FACT Act and the law at issue in Casey, and argued that Casey should have applied. ${ }^{268}$ The missing piece in the dissent's analysis is that the FACT Act's notice requirements and the abortion-specific informed consent laws are not actually informed consent requirements. The informed consent process requires that medical providers use their professional judgment to inform patients about the risks and benefits associated with a medical treatment. ${ }^{269}$ The information required for informed consent cannot be packaged in a script determined by the government.

In certain informed consent laws, state ideological speech masquerades as medically necessary information. This is unconstitutional. In Casey, Planned Parenthood unsuccessfully argued that a Pennsylvania informed consent law violated the First Amendment. ${ }^{270}$ The Court rejected this argument in three sentences:

All that is left of petitioners' argument is an asserted First Amendment right of a physician not to provide information about the risks of abortion, and childbirth, in a manner mandated by the State. To be sure, the physician's First Amendment rights not to speak are implicated, but only as part of the practice of medicine, subject to

\footnotetext{
health, to prevent false advertising, and to encourage pregnant women to consult medically licensed health professionals.").

266. "The stated purpose of the FACT Act ... is to ensure that California residents make their personal reproductive health care decisions knowing their rights and the health care services available to them." NIFLA, $138 \mathrm{~S}$. Ct. at 2369 . For example, one pregnant woman sought prenatal care at a CPC and began displaying abnormal symptoms in her pregnancy. Molly Redden, One State Finally Cracked Down on Crisis Pregnancy Centers, MOTHER JONES (Oct. 12, 2015), http:// www.motherjones.com/politics/2015/10/state-just-became-first-crack-down-deceptive-anti-abortionpregnancy-centers [https://perma.cc/55WW-RZ78]. The woman had diabetes, but the CPC provided no treatment to lower her abnormally high blood sugar levels. Id. Dr. Sally Greenwald, an OBGYN who later cared for the woman, explained that because the CPC failed to address her diabetes, "[t]he fetus was exposed to lifelong risks, such as cardiac malformations, brain abnormalities, and spine deformations." Id.

267. See NIFLA, 138 S. Ct. at 2385-86 (Breyer, J., dissenting)

268. See id. at 2383-85.

269. See Informed Consent, AM. MED. Ass'N, supra note 45

270. See Reply Brief for Petitioners and Cross-Respondents at 20-22, Planned Parenthood of Se. Pa. v. Casey, 505 U.S. 833 (1992) (Nos. 91-744, 91-902), 1992 WL 551420.
} 
reasonable licensing and regulation by the State. We see no constitutional infirmity in the requirement that the physician provide the information mandated by the State here. ${ }^{271}$

Contrast this with NIFLA, which held that "[s]peech is not unprotected merely because it is uttered by "professionals," 272 and recognized only two exceptions to the general rule that content-based regulations are subject strict scrutiny analysis: (1) laws that require the disclosure of "purely factual and uncontroversial information about the terms under which... services will be available", ${ }^{273}$ and (2) laws that regulate "professional conduct" that "incidentally involves speech." 274 The comparison of Casey and NIFLA brings to light the double standard at play. The Supreme Court cannot allow informed consent laws like those at issue in Casey to stand and at the same time strike down the FACT Act in NIFLA. Alternatively, if the Court is right in finding that strict scrutiny should apply to the FACT Act, abortion informed consent laws must also be invalidated on free speech grounds. The Court cannot choose to apply an inconsistent standard that favors one set of speakers.

Applying the standard set forth in NIFLA to abortion informed consent laws in effect in Kansas, South Dakota, Indiana, and other states with similar statutes, demonstrates these informed consent laws burden the speaker's First Amendment rights. Under NIFLA, all content-based regulations burden free speech and are "presumptively unconstitutional." 275

\section{The Kansas Abortion Informed Consent Law Is Unconstitutional}

The Kansas abortion-specific informed consent law is a contentbased regulation, and thus is presumptively unconstitutional and subject to strict scrutiny under NIFLA. In Kansas, a woman seeking an abortion provides informed consent to the procedure only if she receives a lengthy list of required disclosures. ${ }^{276}$ These required disclosures include, among others: (1) "a description of the proposed abortion method"; (2) "a

271. Casey, 505 U.S. at 884 (plurality opinion) (citations omitted).

272. NIFLA, 138 S. Ct. at 2371.

273. Id. at 2372 (alteration in original) (quoting Zauderer v. Office of Disciplinary Counsel, 471 U.S. $626,651(1985))$.

274. Id.

275. Id. at 2371 (noting that content-based regulations "target speech based on its communicative content" and "are presumptively unconstitutional and may be justified only if the government proves that they are narrowly tailored to serve compelling state interests." (quoting Reed v. Town of Gilbert, 135 S. Ct. 2218, 2226 (2015))).

276. See Kan. StAT. AnN. § 65-6709 (West 2018). 
description of risks related to the proposed abortion method, including risk of premature birth in future pregnancies, risk of breast cancer," as well as "risks to the woman's reproductive health and alternatives to the abortion that a reasonable patient would consider material to the decision of whether or not to undergo the abortion"; (3) "the probable gestational age of the unborn child at the time the abortion is to be performed"; and (4) "the probable anatomical and physiological characteristics of the unborn child at the time the abortion is to be performed."277 The woman must also be informed that:

(1) Medical assistance benefits may be available for prenatal care, childbirth and neonatal care, and that more detailed information on the availability of such assistance is contained in the printed materials given to her and described in K.S.A. 65-6710, and amendments thereto;

(2) the informational materials in K.S.A. 65-6710, and amendments thereto, are available in printed form and online, and describe the unborn child, list agencies which offer alternatives to abortion with a special section listing adoption services and list providers of free ultrasound services;

(3) the father of the unborn child is liable to assist in the support of her child, even in instances where he has offered to pay for the abortion except that in the case of rape this information may be omitted;

(4) the woman is free to withhold or withdraw her consent to the abortion at any time prior to invasion of the uterus without affecting her right to future care or treatment and without the loss of any state or federally-funded benefits to which she might otherwise be entitled;

(5) the abortion will terminate the life of a whole, separate, unique, living human being; and

(6) by no later than 20 weeks from fertilization, the unborn child has the physical structures necessary to experience pain. There is evidence that by 20 weeks from fertilization unborn children seek to evade certain stimuli in a manner that in an infant or an adult would be interpreted to be a response to pain. Anesthesia is routinely administered to unborn children who are 20 weeks from fertilization or older who undergo prenatal surgery. ${ }^{278}$

The Kansas statute is a content-based regulation of speech because it compels physicians to speak a particular message. ${ }^{279}$ There is no

277. Id. at $\S 65-6709(\mathrm{a})(2)-(5)$.

278. Id. § 65-6709(b).

279. See NIFLA, 138 S. Ct. at 2371. 
"professional speech" exception that may apply. ${ }^{280}$ Further, neither exception recognized in NIFLA applies. First, "laws that require professionals to disclose factual, noncontroversial information in their "commercial speech"' are not subject to strict scrutiny. ${ }^{281}$ Most of the Kansas statute's disclosure requirements, however, are not factual. It is well established that there is no relationship between abortion and breast cancer. $^{282}$ The most common type of abortion procedure poses no increased risk of infertility or sterility for women later in life and the less common abortion procedures pose only a two percent chance of sterility. ${ }^{283}$ Abortion is usually a safe procedure ${ }^{284}$ and does not pose an increased risk of complications in future pregnancies. ${ }^{285}$

Even if these disclosures were factual, abortion is, as Justice Thomas himself put it, "anything but an 'uncontroversial' topic." ${ }^{286}$ Most of the disclosure requirements in Kansas are extremely controversial and based on the state's ideological view that abortion is immoral. The required disclosure that the fetus at twenty weeks "has the physical structures necessary to experience pain," 287 as well as the disclosure of the gestational age and anatomic features of the fetus, ${ }^{288}$ are included to

280. See id. at 2371-72 ("Speech is not unprotected merely because it is uttered by "professionals."). But see id. at 2375 ("[N]either California nor the Ninth Circuit has identified a persuasive reason for treating professional speech as a unique category that is exempt from ordinary First Amendment principles. We do not foreclose the possibility that some such reason exists.").

281. Id. at 2372 (quoting Zauderer v. Office of Disciplinary Counsel, 471 U.S. 626, 651 (1985)).

282. See Abortion, Miscarriage, and Breast Cancer Risk: 2003 Workshop, NAT'L CANCER INST. (Jan. 12, 2010), https://www.cancer.gov/types/breast/abortion-miscarriage-risk [https://perma.cc /QY24-YRCN] (providing a review of studies concluding abortion and miscarriage are "not associated with an increase in breast cancer risk"); MINORITY STAFF OF H.R. COMM. ON GOV'T REFORM, 109TH CONG., FALSE AND MiSLEADING HEALTH INFORMATION PROVIDED BY FEDERALLY Funded PREGNANCY RESOURCE CENTERS 7-9 (2006) [hereinafter WAXMAN REPORT] ("There is a medical consensus that there is no causal relationship between abortion and breast cancer.").

283. Hani K. Atrash \& Carol J. Rowland Hogue, The Effect of Pregnancy Termination on Future Reproduction, 4 BAILliÈRE's CliniCAL OBSTETRICS \& GyNAECOLOGY 391, 391-405 (1990); see also F. GARY CUNNINGHAM ET AL., WiLliAMS OBSTETRICS 877 (21st ed. 2001) ("Fertility is not altered by an elective abortion.").

284. David A. Grimes, Estimation of Pregnancy-Related Mortality Risk by Pregnancy Outcome, United States, 1991 to 1999, 194 AM. J. OBSTETRICS \& GYNECOLOGY 92 (2006) (stating that abortion has the lowest risk of pregnancy-related maternal death of all pregnancy outcomes studied).

285. See Yvonne Butler Tobah, Could an Abortion Increase the Risk of Problems in a Subsequent Pregnancy?, MAYO CLINIC (July 19, 2017), https://www.mayoclinic.org/healthy -lifestyle/getting-pregnant/expert-answers/abortion/faq-20058551 [https://perma.cc/WT5B-7WYH] ("Generally, elective abortion isn't thought to cause fertility issues or complications in future pregnancies.”).

286. NIFLA, 138 S. Ct. at 2372.

287. KAN. StAT. ANN. $\S 65-6709$ (b)(6) (West 2018).

288. Id. § 65-6709(a)(4)-(5). 
insinuate the "unborn child" may be experiencing pain. ${ }^{289}$ Further, the fetal pain disclosure requirement is not supported by the available evidence. ${ }^{290}$ In 2005, a multidisciplinary review published in the Journal of the American Medical Association found that the gestational brain developments necessary for a fetus to experience pain do not occur until the third trimester, concluding: "Pain is an emotional and psychological experience that requires conscious recognition of a noxious stimulus. Consequently, the capacity for conscious perception of pain can arise only after thalamocortical pathways begin to function, which may occur in the third trimester around 29 to 30 weeks' gestational age."291

The required disclosures on available resources and child support may also be false, misleading, or unrelated to the services offered by the abortion provider. The availability of a child support obligation depends on unique circumstances of the parents and needs of the child, as "[e]ach case is different." ${ }^{292}$ Further, the required disclosure about the potential availability of other state-sponsored resources like Kan-Care "in no way relates to the services the licensed clinics provide," but rather "statesponsored services." ${ }^{293}$ Lastly, the required disclosure that abortion will "terminate the life of a whole, separate, unique, living human being" 294 is controversial because it requires physicians to speak the state's ideological viewpoint on an unsettled medical, philosophical, and theological issue: whether the fetus is a human being. ${ }^{295}$ A state may not impose speech on a physician regarding this controversial topic when "the unborn have never been recognized in the law as persons in the

289. See Tobin, supra note 57, at 144-45 ("The reasonable lay reader would be likely to infer that when 'the necessary structures' are in place, pain perception can occur. . . [But] it appears that [the neural structures necessary for pain perception] are not meaningfully functional until the start of the third trimester, about twenty-nine to thirty weeks' gestational age.").

290. Lindsay J. Calhoun, The Painless Truth: Challenging Fetal Pain-Based Abortion Bans, 87 Tul. L. REV. 141, 163-64 (2012) (quoting Susan J. Lee et al., Fetal Pain: A Systematic Multidisciplinary Review of the Evidence, 294 J. AM. MED. ASs'N 947, 952 (2005)).

291. Lee et al., supra note 290.

292. Linda D. ElRoD, 2 KAN. LAW \& PraC., FAMILY LAW $\S 14: 16$, Westlaw (database updated Dec. 2019). But see Fargo Women's Health Org. v. Schafer, 18 F.3d 526, 533-34 (8th Cir. 1994) ("The provision discussing medical assistance provides that the required benefits 'may be available,' not that they are available. The statement that the father is liable to assist in supporting the child finds its support in other North Dakota statutes. If in certain cases such a statement would be misleading or false, it would undoubtedly be because of unique and personal background facts that would be at least suspected if not known to the woman." (citations omitted)).

293. Nat'l Inst. of Family \& Life Advocates v. Becerra, 138 S. Ct. 2361, 2372 (2018).

294. KAN. StAT. ANN. § 65-6709(b)(5) (West 2018).

295. See Roe v. Wade, 410 U.S. 113, 159 (1973) ("We need not resolve the difficult question of when life begins. When those trained in the respective disciplines of medicine, philosophy, and theology are unable to arrive at any consensus, the judiciary, at this point in the development of man's knowledge, is not in a position to speculate as to the answer."). 
whole sense." 296

The second exception set forth in NIFLA also is inapplicable because these mandatory disclosures are not regulating professional conduct that incidentally burdens speech. The Kansas statute's required disclosures are not informed consent requirements. The Kansas statute requires disclosures about unrealistic risks, available resources, and child support to all women seeking abortion, regardless of whether the information will be of no use, such as to women who are married, women who are already fully appraised of their options because they have had the procedure before, and women who have concluded that abortion is the only reasonable option. ${ }^{297}$ Finally, the disclosure requirements related to the termination of the fetus and the probable gestational age are not informed consent requirements because this information is irrelevant to a woman's choice on whether or not to obtain an abortion. ${ }^{298}$ The information required for informed consent is centered on professional judgment calls, ${ }^{299}$ and while some of the required disclosures discussed above are based in fact, the disclosure does not serve a practical purpose. Because the Kansas informed consent disclosure requirements are not informed consent requirements, they "regulate[] speech as speech" and the exception does not apply. ${ }^{300}$

Because the NIFLA exceptions to the application of strict scrutiny to content-based regulations of speech would not apply, the Kansas statute would be analyzed under strict scrutiny, which it would fail. The Kansas statute will survive strict scrutiny only if Kansas could demonstrate that: (1) the governmental interest is compelling; and (2) that the statute is narrowly tailored as the least restrictive means to accomplish the regulatory goal. ${ }^{301}$ The governmental interest is compelling, ${ }^{302}$ but the statute is not narrowly tailored to serve the compelling interest. ${ }^{303}$ Just like California's regulatory goals could be met by less burdensome means in NIFLA, Kansas's regulatory goals could also be met by less

296. Id. at 162 .

297. See Planned Parenthood of Se. of Pa. v. Casey, 505 U.S. 833, 921 (Stevens, J., concurring in part and dissenting in part).

298. Vandewalker, supra note 26, at 9-10.

299. Informed Consent, AM. MED. ASs'N, supra note 45.

300. Nat'l Inst. of Family \& Life Advocates v. Becerra, 138 S. Ct. 2361, 2374 (2018).

301. Id. at 2371 .

302. Roe v. Wade, 410 U.S. 113, 154 (1973) (“[A] State may properly assert important interests in safeguarding health, in maintaining medical standards, and in protecting potential life. At some point in pregnancy, these respective interests become sufficiently compelling to sustain regulation of the factors that govern the abortion decision.").

303. NIFLA, $138 \mathrm{~S}$. Ct. at 2376. 
burdensome means like providing the information in advertising campaigns or posting information on public property near an abortion clinic. ${ }^{304}$ "The First Amendment does not permit the State to sacrifice speech for efficiency." ${ }^{305}$ Because less burdensome means are available, the statute likely fails strict scrutiny.

\section{Other State Informed Consent Laws Incorrectly Stating Risks of Abortion Are Also Unconstitutional}

South Dakota's abortion-specific informed consent statute is similarly unconstitutional. Like the Kansas statute, it requires disclosure that the abortion terminates "the life of a whole, separate, unique, living human being." 306 Further, it requires a statement that the patient "has an existing relationship with that unborn human being."307 The statute also contains a required disclosure related to the "risks" of abortion, including an increased risk of suicide and infertility. ${ }^{308}$ Both of these "risks" are unsupported by medical evidence. ${ }^{309}$ Lastly, having an abortion does not put a woman at risk of significant psychological harm. ${ }^{310}$ In fact, the scientific evidence shows that women who carry to term experience need for psychological treatment at the same rate as women who have had an abortion. ${ }^{311}$

Indiana's abortion-specific informed consent requirement is unconstitutional as well. The physician is required to inform the woman of the risks to the "potential danger of infertility," "danger to subsequent pregnancy," "[t]hat human physical life begins when a human ovum is fertilized by a human sperm," and that an ultrasound image and "auscultation of fetal heart tone[s]" are available. ${ }^{312}$ There are likely many other states that restrict abortion in similar ways to Kansas, South Dakota, and Indiana because the vast majority of states restrict access to abortion in some way. ${ }^{313}$ Such restrictions would necessarily burden the

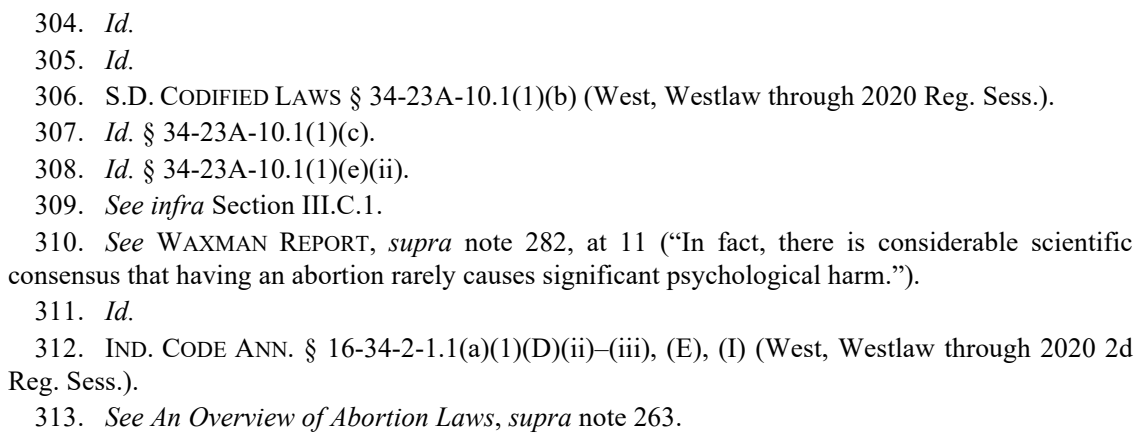


physician's First Amendment rights under NIFLA.

These government-scripted disclosures while serving a compelling interest, are not narrowly tailored. Just like Kansas, South Dakota and Indiana could publish information on abortion or alternatives to abortion, including state resources, on a government website or in advertisements. The manipulation of informed consent into a government mandated script transforms the physician into a mouthpiece of the government to espouse ideological views about the life of the fetus or to disclose "risks" that are not tied to the procedure at all, and there are less burdensome ways the state could inform women of this view without impacting the speech of the physician.

Many, if not all, state abortion disclosure requirements could be found unconstitutional based on the holding in NIFLA that all contentbased regulations are subject to strict scrutiny unless two narrow exceptions apply. These laws do not "facilitate informed consent to a medical procedure," 314 as the required scripts physicians must read do not provide medically necessary "information about the risks or benefits" of abortion. ${ }^{315}$ Rather, states are purportedly using their "regulatory authority to show [their claim of] profound respect for the life within the woman," when there are less burdensome means to do so. ${ }^{316}$

For example, many states require physicians to inform women about adoption and the right to seek child support from the father. ${ }^{317}$ This information has nothing to do with the medical procedure, indicating that the laws are not narrowly tailored. The alternative to abortion is carrying a child to term, not carrying a child to term and giving up parental rights or initiating an action to establish child support. Tellingly, the only difference between these required disclosures and the FACT Act's notice requirements is ideological viewpoint. The First Amendment applies equally to medical providers advocating anti-abortion beliefs and to those who are pro-choice. Thus, NIFLA has paved the way for physicians to successfully challenge these state informed consent laws as a violation of their First Amendment rights.

314. Nat'l Inst. of Family \& Life Advocates v. Becerra, 138 S. Ct. 2361, 2373 (2018).

315. Id.

316. Gonzales v. Carhart, 550 U.S. 124, 128 (2007).

317. Rachel Benson Gold \& Elizabeth Nash, State Abortion Counseling Policies and the Fundamental Principles of Informed Consent, GUTTMACHER InST. (Nov. 8, 2007), https:// www.guttmacher.org/gpr/2007/11/state-abortion-counseling-policies-and-fundamental-principles-in formed-consent\# [https://perma.cc/U2XC-DUDB] (noting that twenty-three states have counseling requirements, many of which involve counseling on the option of adoption). 


\section{Protecting the First Amendment and Preserving Medical Ethics After NIFLA}

The FACT Act tried to accomplish too much and was too broad to regulate CPCs. Some predicted that the FACT Act was the answer to regulating CPCs and served as a model for how other states may frame their own laws to protect their most marginalized women. ${ }^{318}$ The ultimate answer is that informed consent laws are subject to strict scrutiny analysis and must be unconstitutional when they are not based in fact or sufficiently tailored to the offered medical procedures.

To cure the problem with the FACT Act, California could pass new legislation that meets the exception for the regulation of professional conduct recognized in NIFLA. A new act could incorporate the FACT Act definitions of licensed and unlicensed clinics and keep the notice requirements. $^{319}$ A content-based regulation of professional conduct, however, must tie the medical counseling services to the required notices to satisfy the standard set forth in NIFLA. This may be done by revising the language in section 123472 as follows:

When a patient suspects she is pregnant, or has been confirmed to be pregnant either from a test taken at the clinic or before coming to the clinic and she seeks prenatal care, abortion services, or other counseling related to her pregnancy, the clinic must inform her: (1) if the clinic is licensed or unlicensed; (2) if the clinic provides abortion; (3) that she may qualify for public programs that provide immediate free or low-cost access to comprehensive family planning services (including all FDA-approved methods of contraception), prenatal care, and abortion for eligible women; and (4) that to determine whether she qualifies, she must contact the county social services office.

By tying the notice to a confirmed or suspected pregnancy and the medical counseling related to her suspected or confirmed pregnancy, the FACT Act could be interpreted as a constitutional regulation of professional conduct and would allow states to regulate the deceptive

318. Beth Holtzman, Note, Have Crisis Pregnancy Centers Finally Met Their Match: California's Reproductive FACT Act, 12 Nw. J.L. \& SOC. POL'Y 78, 79 (2017) (“Since 2009, four cities and one county have passed similar ordinances attempting to regulate CPCs through mandatory disclosure requirements. Although most of these laws were struck down for purportedly violating CPCs' freedom of speech and free exercise of religious rights, it is likely that California's Reproductive FACT Act will continue to withstand these constitutional challenges because of features of the FACT Act that distinguish it from the other similar ordinances. The FACT Act successfully addresses the shortcomings of the previous legislation and was drafted to survive First Amendment challenges.").

319. See supra Section II.D. 
practices of CPCs once and for all.

\section{CONCLUSION}

The Ninth Circuit should find that the FACT Act fails strict scrutiny because it was not narrowly tailored. Regardless of the Ninth Circuit's finding, physicians may now have a better chance to challenge paternalistic informed consent laws on abortion because of NIFLA. This may have the potential to invalidate abortion informed consent laws but uphold future laws that regulate CPCs.

Informed consent requires the discussion of the risks and benefits of procedures and treatment. ${ }^{320}$ While the words "truth," "facts," or "free of ideology" are nowhere to be found, a plain reading of the informed consent standard makes clear that in order for a patient to make an informed choice, knowledge and comprehension are essential prerequisites. ${ }^{321}$

320. See Informed Consent, BLACK's LAw Dictionary (11th ed. 2019).

321. Id.; see also Informed Consent, AM. MED. Ass'N, supra note 45. 